\title{
Regulation and Administered Contracts Revisited: Lessons from Transaction-Cost Economics for Public Utility Regulation ${ }^{1}$
}

\author{
KEITH J. CROCKER \\ The Pennsylvania State University \\ Department of Economics, University Park, PA 16802 \\ SCOTT E. MASTEN \\ University of Michigan \\ School of Business Administration, Ann Arbor, MI 48109
}

\begin{abstract}
This article reexamines the administered contracts approach to regulation in light of recent empirical research that establishes the importance of transaction-costs in the organizational choice and design decisions. After reviewing the fundamentals of transaction cost reasoning and the franchise bidding-versus-regulation debate, the study surveys the empirical literature on franchise bidding, contracting, and vertical integration. The implications of transaction-cost theories for current policies toward pubic utility regulation and deregulation are also addressed.
\end{abstract}

\section{Introduction}

Although transaction-cost economics has had its greatest influence on the analysis of vertical integration and contracting, many of the central arguments and concepts identified with modern transaction-cost theory trace their origins to the regulatory debates of the $1960 \mathrm{~s}$ and 1970s. Spurred by Harold Demsetz' (1968) franchise-bidding solution to the natural monopoly problem, Oliver Williamson (1975) and Victor Goldberg (1976) set out the first detailed, comparative analyses of the roles and limitations of markets and regulation as alternative institutions for the governance of public utility transactions. The problems communities encountered in the procurement of public utility services were, as it turned out, isomorphic to the problems private firms faced in deciding whether to make or buy intermediate goods and in designing and administering contractual relations. Because of its relative tractability, transaction-cost theory concentrated on vertical integration and contract-

1 We would like to thank Michael Crew, Victor Goldberg, Mark Lowry, Claude Menard, and Roger Sherman for helpful comments. 
ing issues in nonregulatory settings in its subsequent development. (See, especially, Klein, Crawford, and Alchian (1978) and Williamson (1975; 1985).) But that development was and continues to be informed by arguments and insights generated in the debate over franchise bidding versus regulation.

A variety of factors combine to make this an appropriate time for an appraisal of developments in transaction-cost economics in the ensuing years and their implications for public utility regulation. First, considerable progress has been made in both the content and evaluation of transaction-cost theories of organization. In particular, a substantial body of empirical evidence now underlies the theory of governance choice and design. Second, a number of major changes have occurred in technology and the regulatory environment of public utilities. Whereas public utilities have traditionally exhibited a high degree of vertical integration, with production, transmission, and distribution often organized within a single firm, recent public policies have fostered increasing vertical disintegration in the utilities sector. The well-documented separation of local access and long-distance service occasioned by the AT\&T breakup is probably the most prominent example, but similar trends have occurred in electricity, where generation is increasingly becoming the domain of independent firms (Joskow 1991a), and in natural gas, where sales and transportation have been largely unbundled (Teece 1990; DeCanio and Frech 1993; Lyon and Hackett 1993). More arms-length exchanges are thus replacing vertical integration in a number of regulated environments. Yet, the alternative is rarely the competitive spot market seemingly envisioned by regulators. Instead, long-term contracts appear to be the preferred norm.

These changes in the institutional and regulatory structure of the public utility sector have resulted in a number of important policy questions. The first concerns the efficiency consequences of the movement away from a vertically integrated institutional structure. To the extent that the government has imposed vertical disintegration through the courts (AT\&T), regulatory agencies (FERC), or legislation (PURPA 1978), what are the likely efficiency effects? The second relates to the design of the most efficient regulatory framework in a vertically disintegrated environment. How, for example, does the procurement of inputs through long-term contracts influence the appropriate design of regulations? The recent empirical work on transaction costs and optimal institutional choice provides guidance on both counts. Finally, the transaction cost, or administered contracts, view of regulation represents an alternative to the mechanism design perspective that dominates much of the current theoretical literature on regulation. This paper represents an opportunity to interpret and assess that literature through a tiansacion-cost lens.

The structure of the paper is summarized in table 1 . Our discussion begins with a general overview of transaction cost reasoning and theory, followed by a recapitulation of the franchise bidding-administered contracts debate. The third section contains a summary of the empirical research on public utility regulation that addresses the issues and hypotheses developed within the administered contracting framework, followed by a broader review of the empirical transaction-cost literature. Section four develops some of the implications of this literature for regulatory policy, and a final section contains concluding remarks.

\section{Transaction Costs, Institutional Choice, and Administered Contracts}

\subsection{Fundamentals of Transaction-Cost Reasoning}

The logical foundation for analyzing organization and governance issues in transaction-cost terms is Coase's (1960) insight that all potential gains from trade would be realized but for 
Table 1. Organization of the Article

1. Introduction

2. Transaction Costs, Institutional Choice, and Administered Contracts

2.1 Fundamentals of Transaction-Cost Reasoning

2.2 Regulation and Administered Contracts

3. Empirical Research on Transaction Costs and Institutional Choice

3.1. Franchise Bidding and Regulation

3.1.1 Cable television

3.1.2 Other studies of public utility governance

3.2. Long-Term Contracting

3.2.1 Contract duration

3.2.2 Contract design

minimum purchase requirements

contract prices

methods of price determination

effects of external regulation

3.3 Vertical Integration

3.4 Governance Choice and Performance

4. Lessons for the Current Regulatory Debate

5. Conclusions

transaction costs. As Coase demonstrated, problems such as externalities that were conventionally believed to require government intervention could be resolved through private negotiations if the costs of reaching and enforcing agreements were negligible. Since the costs of bargaining and contracting are what prevent parties from securing all potential gains from trade, the merits of markets relative to government regulation turn on the magnitude of those costs relative to the costs of governing exchange administratively.

Coase's insight was important both for drawing attention to the potential for transactors to resolve on their own problems that were thought to require government action and for demonstrating that the efficiency of alternative institutional arrangements turned on transaction cost comparisons. But Coase's analysis, which called for direct comparisons of transaction costs under alternative institutions, left open the question of which institution was best in any particular circumstance. ${ }^{2}$ Because transaction costs can, at best, only be observed for institutions that are actually chosen, the relative merits of proffered alternatives remained a matter of mere speculation.

This limitation of transaction cost reasoning began to be addressed in the 1970s with the application of the theory to a question that Coase (1937) had earlier identified as a transaction cost issue: the boundaries of the firm. Following Coase, Oliver Williamson $(1971 ; 1979)$ reasoned that the choice between market and vertically integrated transactions turned on a comparison of the costs of transacting under each. But Williamson recognized that "operationalizing" the theory required predicting when the costs of transacting under one arrangement were likely to be larger than under another. Accomplishing this entailed (i) identifying

2 The exception is Coase's observation that administrative costs of organizing transactions are likely to be high when diverse transactions are brought within the control of a single organization $(1991,25 ; 1960,17)$. 
the properties that distinguished organizational alternatives from one another, (ii) recognizing the costs associated with governing exchange under each alternative, and (iii) relating the incidence of those costs to observable dimensions of the transaction in a discriminating fashion.

According to that analysis, alternative institutional arrangements differ in the extent to which they offer protection against opportunism and in the demands they place on managers' limited time and attention. Spot market transactions or, more generally, simple day-to-day exchanges provide transactors considerable autonomy and flexibility in the periods both leading up to and following the actual transaction. In such transactions, parties are generally free to bargain or not bargain as they please. Moreover, once a transaction is consummated, the parties have relatively few ongoing obligations and may, for example, use or dispose of the items procured in whatever manner they choose. ${ }^{3}$

The latitude afforded transactors in simple exchanges provides them both the ability and the incentive to adjust their behavior to events and information as they arise. That latitude, however, also provides transactors a tactic to extract rents. Parties to a simple exchange may haggle, stall, or walk away from the deal altogether if they are dissatisfied with the terms of trade currently tendered. Although the existence of a large number of potential trading partners limits such conflict over the terms of trade, transactors are often able to realize cost economies or design benefits by making investments in relationship-specific assets. Such investments can take at least four forms: (i) physical-asset specificity, which refers to investments in equipment such as tooling or equipment specially designed for a particular customer; (ii) site or location specificity, which occurs when a buyer or seller locates his facilities next to the other to economize on transportation costs; (iii) human-capital specificity, which arises when one or both parties develop skills or knowledge valuable only when dealing with the other; and (iv) dedicated assets, which are investments made to support exchange with a particular customer that, though not specific to that customer, would result in substantial excess capacity were that customer to discontinue purchases. ${ }^{4}$

Although such investments enhance the value of exchange with a particular customer, they have a discretely lower value in their next best use and, once made, effectively lock the buyer and seller into a bilateral trading relationship. The more difficult it is to find substitute performance or to redeploy investments to alternative uses, the larger the appropriable quasi-rents and the greater the risk that transactional surpluses will be dissipated as the parties engage in hold ups or other forms of opportunistic behavior attempting to influence the terms of trade in their favor.

Contracting represents an attempt to attenuate such hold up problems by defining acceptable behavior at the outset of the relationship. But contracting is also subject to a

3 The existence of product liability and implied warranty obligations are exceptions to this generalization.

4 An example of dedicated assets, and one that is exploited by Joskow (1987), is the capacity that a coal mine might dedicate to a large purchaser of coal, such as an electric utility. If the market for such large quantities of coal is relatively thin, then a failure to accept delivery by the purchaser would leave the mine with productive assets which could not be readily redeployed to an alternative use. Similar arguments have been made, perhaps with justification, in cases where producers of electrical power have lost load to self-generation.

In addition to the conditions listed above, the threat of hold ups may also arise, or be exacerbated, where the timing of performance is important. See discussion in section 3.3 . 
variety of hazards that limits its usefulness. In particular, because contingent agreements are costly to compose and difficult for courts to interpret and enforce, contracts are inevitably incomplete. Although parties will design contracts to balance the need for adaptation with the cost of effecting adjustments, the inability to define precise obligations in response to changing events in ways that can be enforced at low cost means that contracts will, on the one hand, tend to be inflexible and, on the other, leave considerable opportunity to cheat on the agreement or to attempt to evade performance.

Transactors respond to the inability to write complete contracts in two ways. First, as the transaction becomes more complex or uncertain, contracts are likely to become more "relational" in character. Rather than attempting to lay out a detailed specification of the terms of the agreement, relational contracts attempt simply to establish the process through which future terms of trade will be determined - "the establishment, in effect, of a constitution governing the ongoing relationship" (Goldberg 1976, 428; see also Williamson 1979). Second, parties will seek to reduce the costs of being bound to long-term agreements by adopting agreements of shorter duration. The latter course, however, confronts a tradeoff between the savings from reducing the duration of the contract by an additional period and the hazard of negotiating follow-on procurements in a condition of bilateral monopoly.

When the hazards of spot market and contractual exchange are severe, vertical integration offers potential ownership and governance advantages. By allocating residual rights of control over the use and disposition of assets, ownership restricts the ability of nonowners to withhold assets from production and thus limits hold-up opportunities (Williamson 1971; 1975; 1979; Klein, Crawford, and Alchian 1978; Grossman and Hart 1986). In addition, differences in the legal defaults, sanctions, and procedures governing transactions between employers and employees (vis-a-vis independent contractors) support greater discretion and control in response to change and superior access to information within the firm compared to transactions between independent commercial actors (see Williamson 1991; Masten 1988). The benefits of integration are limited, however, by the bureaucratic inefficiencies that inevitably plague large organizations. Although, in principle, a newly integrated firm should be able to operate at least as efficiently as the two independent firms from which it was formed simply by allowing each division of the combined firm to operate independently as it had before and only intervening where net benefits were likely to be realized, the management of the combined enterprise will be unable, given the law governing internal transactions, to commit to intervening only in such a selective fashion (Williamson 1985; 1991). Without effective assurances that owners will not appropriate performance enhancements, the incentives of division managers to innovate, maintain assets, acquire and utilize information, and otherwise invest in the efficient operation of the division will be compromised. In their place, the firm is forced to substitute weaker, indirect incentives dependent on managerial oversight. ${ }^{5}$ This attenuation of incentives combined with the limited capacity of management to administer addicional transactions-which manifest themselves in a variety of bureaucratic inefficiencies - ultimately undermine the efficacy of internal organization and thereby limit firm size.

5 High-powered incentives refer to the incentive to minimize net receipts that derive from residual claimant status and contrast with the low-powered incentives accruing, for instance, to salaried employees (Williamson 1985, Chapter 6) 


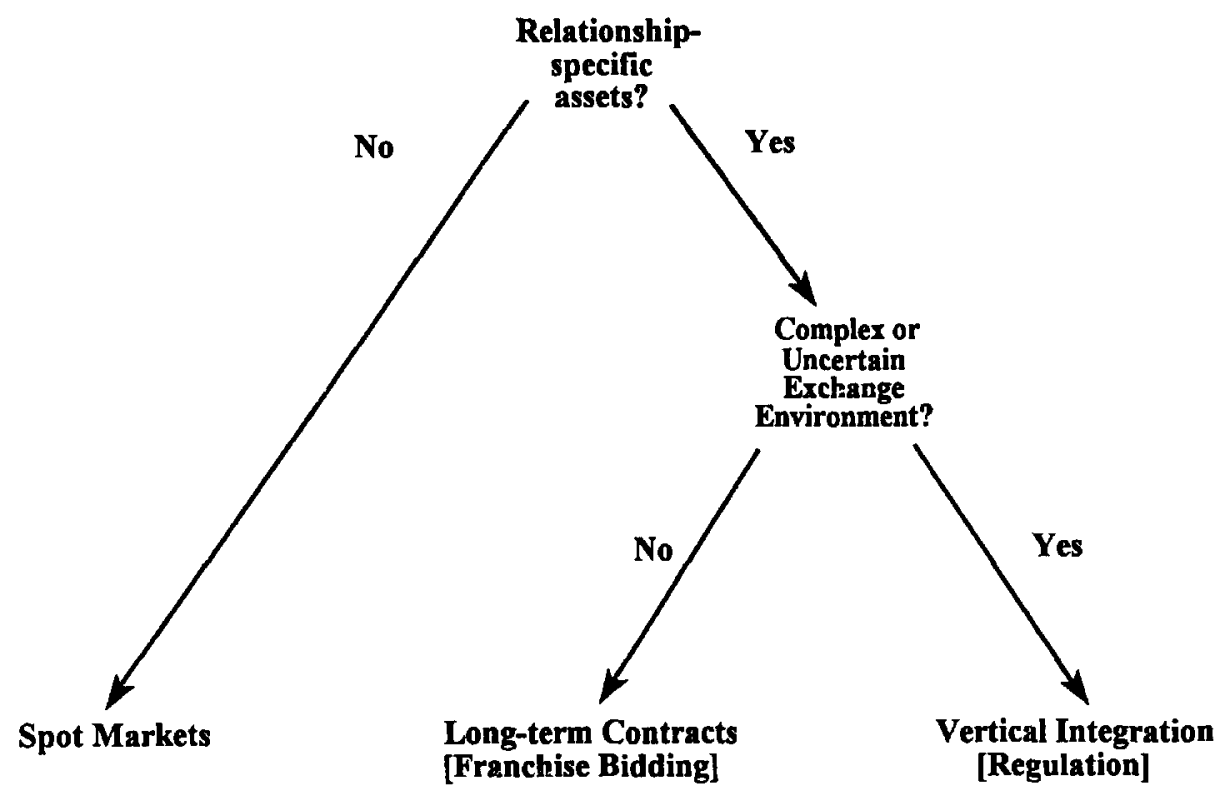

Figure 1. Determinants of Institutional Choice

To summarize, the optimal choice of governance structure-spot markets, long-term contracts, or vertical integration-reflects the desire by the parties to minimize transaction costs. As figure 1 depicts, the potential for opportunism where relationship-specific investments are important leads to a displacement of traditional spot markets by more structured governance alternatives. Where the environment is relatively simple or predictable, the parties may stipulate at the outset a formal assignment of responsibilities, creating a long-term relationship governed by a contractual constitution. As the exchange setting becomes increasingly complex or the negotiation of future duties more costly and problematic, the parties may elect to bear the organizational costs of effecting exchange through internal administration.

\subsection{Regulation and Administered Contracts}

As noted earlier, the transaction-cost theory of vertical integration and the administered contracts perspective on public utility regulation developed in a parallel and largely contemporaneous fashion. The conventional wisdom in the late 1960s was that public utility regulation was a necessary response to natural monopoly cost conditions. According to the natural monopoly rationale, (i) productive efficiency in an industry with declining long-run average costs requires that a single firm serve the market, but (ii) a sole supplier will restrict output to the monopoly level, generating a deadweight loss. Efficiency can only be achieved in such settings if government restricts entry and regulates the price the monopolist can charge to the public.

Using distinctly Coasean reasoning, Harold Demsetz exposed the fallacy in that justification in his classic article, "Why Regulate Utilities?" (1968). ${ }^{6}$ Specifically, Demsetz argued that public utility services could, in principle, be efficiently procured-even where cost conditions dictated a single supplier-simply by awarding a franchise to the firm that 
offered to serve the market at the lowest price. As long as sufficient ex ante competition existed, price would be driven to competitive levels, eliminating the motive for regulation. ${ }^{7}$

From an institutional choice perspective, the crucial aspect of Demsetz' argument was the insight that technological conditions dictated only that a single supplier serve the market; whether the relation between that supplier and consumers was governed by regulation or a more market-like arrangement was a separate question to which the traditional theory of natural monopoly and regulation offered no answer. But in showing that the need for regulation did not follow logically from cost and demand conditions and that market solutions existed that could potentially solve the problem of a single supplier, Demsetz had taken only the first step in the analysis. Whether regulation or franchise bidding was the more effective institution for dealing with natural monopoly remained an open question. Nevertheless, in light of the numerous and well-documented deficiencies of public utility regulation (see, for instance, Posner, 1969), franchise bidding seemed an appealing alternative to regulation. Indeed, Richard Posner judged the promise of franchise bidding so attractive that he raised Demsetz' theoretical challenge to a policy prescription, proposing that " $[\mathrm{m}]$ unicipal authorities...be permitted-and encouraged-to auction off franchises to the firm promising to provide cable service at the lowest rates to subscribers" (Posner 1972, 126). ${ }^{8}$

In separate but parallel rejoinders to Demsetz' challenge and Posner's advocacy, Oliver Williamson and Victor Goldberg argued that the problems associated with contracting solutions in the types of environments encountered in public utility transactions were likely to be severe. First, while competitive bidding can be an effective way of determining the lowest cost supplier where the price of the good or service being procured is the buyer's only concern, competitive bidding works less well for complex goods and services where the buyer cares about quality, reliability, and other attributes of the procurement. Second,

6 In his acknowledgements, Demset $z$ thanks Coase "who was unconvinced by the natural monopoly argument long before this paper was written" $(1968,55)$.

7 Interestingly, this argument was anticipated over one hundred years earlier by Sir Edwin Chadwick (1859), who advocated "competition for the field" of service in railroads, gas, water, taxis, and interment for the dead. Consider, for example, his suggestion for the means by which a unified water and sewage system might be obtained:

"This great field of service might be put up to contractors or companies of competing contractors on this question. 'At what rate will you undertake to abolish [the existing] cesspools of all sorts... and ensure the constant removal of all excretia before it can enter into noxious stages of decomposition[?]...' The answer of efficient competitors, for the whole field... might probably be ... 'We will do it for two pence per week per house...' And I will add, that if the whole field of the metropolis were clear of water companies and were put up for competition upon this question, "At what rate per house will you undertake to provide a supply of pure soft fresh and well aerated spring water for each house?' The answer... might be... "[W]e will do it and keep the distributary apparatus in good, working order for little more than $2 \mathrm{~d}$. per week..' $(1859,403)$.

8 Posner acknowledged a number of potential problems with franchise bidding to the natural monopoly problem, allowing that "A contractual solution to the problem of cable monopoly regulation could turn out to be quite costly; whether it would or not is an unstudied empirical question" $(1972,113)$.

Nevertheless, Posner was generally sanguine about the ability of customers or their representatives to the devise contractual solutions to those problems, as can be seen by comparing his discussion of the prospects and limitations of franchise bidding (1972,110-116) with his enumeration and assessment of the deficiencies of regulation (1969). 
because supplying public utility services typically requires large, durable investments in production and distribution facilities that are specialized to a particular market, the efficient governance of public utility transactions is likely to require long-term contracts to avoid the hazards of repeated haggling over the terms of trade once those investments are in place. Finally, uncertainty about cost and demand conditions over such long horizons and the complexity of public utility services will leave long-term contracts for public utility services inevitably incomplete. Allowing for and effecting adjustments to changing circumstances in franchise agreements are likely to entail contract terms and administrative machinerycost-plus price adjustment, auditing procedures, elaborate and formal dispute resolution processes-that mirror both in character and in costs the administrative apparatus traditionally associated with rate-of-return regulation. ${ }^{9}$ ' Whereas Demsetz' analysis revealed the potential for the efficient supply of public utility services using market arrangements if "irrelevant complications" were ignored (Demsetz 1968, 57), Williamson and Goldberg argued that it was precisely such complications that underlay the choice between regulation and franchise bidding and, further, that the complications that impeded effective regulation were likely to frustrate franchise bidding solutions as well. As Goldberg put it, "The problems are intrinsic to the service, not to the act of regulation itself" $(1976,441)$. Complex or uncertain transactions requiring durable, specialized investments require long-term, incomplete, relational contracts. The choice between franchise bidding and regulation thus becomes largely a question of whether court enforcement or regulator administration is the more effective means of governing those agreements. ${ }^{10}$

9 As Victor Goldberg (1981) points out, A.C. Pigou had raised many of the issues he and Williamson would later emphasize. Pigou, for instance, identified as a substitute for regulation the possibility that "the license to operate certain public utility services [be put up] to a kind of auction" $(1932,373$; cited in Goldberg 1981, 47). Small numbers of bidders and "the fact that the conditions of most industries are continually changing, in such ways that the scheme of price-regulation, which is proper at one time, necessarily becomes improper at another" posed problems for such arrangements, however. In particular, the prospect that the state would take excessive advantage of its power to revise terms would discourage investment, necessitating provisions for adjustment "designed to defend the company's interest" (Pigou 1932, 377; cited in Goldberg 1981, 48). More generally, Pigou demonstrated a remarkably Coasean appreciation of the limitations of governments to correct market failures (Pigou 1932, 331-2; cited in Goldberg 1981, 42-43):

\footnotetext{
"The case [for public intervention to correct gaps between private and social product] cannot become more than a prima facie one, until we have considered the qualifications, which governmental agencies may be expected to possess for intervening advantageously. It is not sufficient to contrast the imperfect adjustments of unfettered private enterprise with the best adjustment that economists in their studies can imagine. For we cannot expect that any public authority will attain, or will even whole-heartedly seek, that ideal. Such authorities are liable alike to ignorance, to sectional pressure and to personal corruption by private interest. ... This objection to public intervention in industry applies both to intervention through control of private companies and to intervention through direct public operation."
}

According to Goldberg, the Pigouvian tradition in welfare economics, of which Coase (1960) was so critical in "The Problem of Social Cost" (1960), represents a diversion from Pigou's own understanding and approach to the problem of market failure.

10 A number of more recent theoretical contributions examine auctions for monopoly franchises and the design of optimal franchise contracts. The approach in this literature has been to examine a one-shot auction for a monopoly right to serve where the bidders either (i) expect to have private information about costs prior to production (Riordan and Sappington 1987); or (ii) possess private information about their 
Thus, as depicted in figure 1, the choice between market and regulatory governance of public utility transactions has direct parallels to the theory of the firm. In each case, the hazards of renegotiation in the presence of relationship-specific investments at the time of contract renewal makes anonymous spot markets unattractive. The shortcomings of franchise Eidding - the public analog to private long-term contracts - are identical to those of its private counterpart. In complex or unpredictable environments, transaction costs are likely to be minimized by removing exchange decisions from the market context and substituting the continuous oversight that regulatory mechanisms entail.

\section{Empirical Research on Transaction Costs and Institutional Choice}

Goldberg's (1976) and Williamson's (1976) arguments regarding the potential shortcomings of franchise bidding relative to regulation were informed by observations of contracting practices in, among other settings, defense procurement, university food services, and cable television. At the time, however, no formal empirical support existed for their arguments. As a result, policy analysts possessed only a new and unsupported theory as the United States entered the great deregulation wave of the late 1970 s and early 1980s. Referring to his 1983 book with Richard Schmalensee, in which they employed transaction-cost reasoning to assess the potential for deregulation in the electric utility industry, Paul Joskow remarked, "I think that Schmalensee and I would have been much happier with our analysis if there had been more (any!) empirical support available for the transactions cost perspective that we found so intuitively appealing and so consistent with the historical evolution of the electric power industry" (1988, 103-104).

In the intervening years, a considerable amount of empirical research bearing both on regulation and on governance issues more generally has been conducted. In the following sections, we review this literature with an eye toward its implications for regulatory policy.

\subsection{Franchise Bidding and Regulation}

\subsubsection{Cable Television}

Williamson supported his theoretical analysis of franchise bidding with a detailed examination of the franchise-bidding experience of the city of Oakland, California. In 1970, the city of Oakland put out invitations to bid for the right to install and operate a cable television system, the award to go to the bidder offering the lowest monthly fee for basic service. The price of second-tier services and annual adjustments to the price of basic service would be determined through subsequent agreement between the franchisee and the city. The 15 -year contract also stipulated damages and provided for termination in the event the franchisee failed to meet the timing requirements of the contract.

Despite safeguards built into the agreement, Oakland suffered many of the problems anticipated in Williamson's and Goldberg's discussions of incomplete contracting, includ-

costs prior to bidding, and also engage in a nonobservable action to reduce costs after receiving the franchise (McAfee and McMillan 1987; Laffont and Tirole 1987). Since these are models of one-shot auctions, however, they are concerned with cost uncertainties at the time the franchise is initially awarded and do not address the franchise renewal problems examined by Goldberg (1976) and Williamson (1976). In contrast, Crew and Harstad (1992) address the asset transfer problem formally in the context of a second-price auction. 
ing: (i) an overly simple award criterion that resulted in misleading and possibly deceptive bidding and a defective award; (ii) disputes over price, quality, and timing during contract execution; and (iii) the inability or unwillingness of the city to exercise its rights to discipline the franchisee by acquiring its assets and transferring them to an alternative operator. In light of these deficiencies, the city's only choices were implementing regulatory controls or accommodating the exercise of monopoly power (Williamson 1976, 101).

Williamson recognized that the experience of a single city might not be representative and therefore could not resolve the debate over the efficacy of franchise bidding for cable television, much less its viability in other settings. Although the study illustrated the hazards to which franchise bidding is exposed and thereby confirmed the existence of the problems anticipated by the theory, determining the magnitude and frequency of those hazards would require more systematic study. Following Williamson, most of the subsequent empirical research addressing the franchise bidding-versus-regulation debate has focused on the cable television industry.

Among the first and most careful of these studies were a series of articles by Robin Prager and by Mark Zupan. Broadly speaking, these studies set out to quantify the extent to which the bidding and contracting problems identified by Williamson and Goldberg materialized in practice. For instance, to determine the actual extent of the potential problems identified by Williamson, Prager (1989) examined the degree of competition at the bidding stage, the sophistication of the award criteria used by franchise authorities, and measures of performance such as construction timing, the level and quality of service, and pricing. Using data on the cable TV franchising experience of 92 Massachusetts communities between 1973 and 1981, Prager concluded that most cable franchises attracted "adequate" competition at the bidding stage and that the timing of system construction, the quality of service, and the frequency and size of price increases were generally reasonable, suggesting that winning bidders did not systematically renege on the franchise agreement. Moreover, the multidimensional criteria used to award franchises were, in her assessment, suitably sophisticated and did not pose undue demands on the franchising authority. Overall, she judged the experience with franchise bidding in Massachusetts to be "quite favorable."

In a second article, Prager (1990) expanded her analysis to the cable franchising experience of 221 communities nationwide. Her survey asked community representatives about their perceptions regarding several dimensions of cable operator behavior including the timing of construction, service quality, operator responsiveness, and whether serious disputes with the cable operator had ever arisen. She then regressed these against a variety of demand and cost variables plus dummy variables for firms that operated more than twenty cable systems (as a proxy for reputation), the existence of state or local rate regulation, and whether the community awarded franchises competitively. Her main findings were that communities were more satisfied with cable system performance when dealing with large, multiple system operators and where the franchise award process was noncompetitive. Rate regulation, whether at the state or local level, meanwhile, led to a significant deterioration in reported satisfaction with performance for five of her eight measures of operator performance. Again, Prager concluded that, overall, most communities appeared to be pleased with the services they received and that, even though a substantial number reported having had problems in one or more performance dimensions, the degree of opportunism was not terribly severe. $^{11}$

Zupan's (1989a) effort to assess the cable franchising experience employed survey data from 66 cable systems. Zupan focused on two issues: the determinants of cable rates and 
the extent of operator opportunism and reneging during contract execution. His results regarding cable rate determination showed that rates tended to be lower the more competition during franchise bidding, suggesting that franchise bidding had some success in restraining prices, ${ }^{12}$ but that nonprice concessions to local governments such as free hookups to public institutions, community programming, and franchise system royalties resulted in significantly higher prices for both basic and premium services. Zupan concluded that operator opportunism and reneging were infrequent, however, and that unforeseen circumstances rather than opportunism were the primary motivation for operator-induced renegotiations.

Finally, to test whether advantages possessed by incumbent cable operators allowed them to behave opportunistically at franchise renewal intervals, Zupan (1989b; 1989c) compared a sample of 59 cable franchise renewal agreements with 66 concurrent initial franchises. Although only 7 of 3516 cable communities nationwide did not renew contracts with the incumbent supplier, suggesting a lack of bidding parity between incumbents and potential entrants at contract renewal, Zupan found that, out of six franchise terms examined, new and renewal contracts differed significantly only with respect to channel capacity and the price of the leading pay tier of service. He attributed the lack of evidence of serious opportunism problems with franchise bidding in both studies to reputational concerns, the use of penalty clauses, cities' bargaining power, and the threat of vertical integration, all of which act as constraints on system operator opportunism.

Overall, Prager and Zupan paint a generally positive picture of the experience with franchise bidding in the cable TV industry. But despite the thoroughness of their analyses, the limited variance in the institutional, demand, and technological features of the cable TV industry hinder generalizations about both the performance of franchise bidding for cable TV and the prospects for extending it successfully to other industries. In particular, these studies have attempted to evaluate the efficacy of franchise bidding in absolute terms, when the relevant question from an institutional choice perspective is how well franchise bidding performs relative to governance of the same transaction through regulation. Thus, Zupan and Prager are able to conclude that franchise bidding has been efficacious despite evidence that over $20 \%$ of the communities surveyed reported having experienced major disputes with operators, construction delays, fair to poor quality, and other problems (Prager 1990, 216). Without a basis for comparison, judgements regarding the performance of franchise bidding are inescapably subjective. ${ }^{13}$

11 In another study, Prager (1992) examined financial market data to ascertain the effects of deregulation on cable television operators, and concluded that deregulation resulted in increased profits. Similarly, Carroll and Lamdin (1993) found, in an event study analysis of CATV stock prices, that news of the failure of proposed legislation to reregulate cable services resulted in positive abnormal returns.

12 Beil, Dazzio, Ekelund, and Jackson (1993) found that competition among the suppliers of cable television services resulted in substantial reductions in cable rates.

13 Although Prager (1990) includes institutional dummies for state and local rate regulation and for the use of competitive bidding in her analysis, these variables are treated as exogenous. If, however, the decision to employ these arrangements were made systematically to reflect their expected performance, then results with regard to these variables will be biased. More generally, given that the dominance of franchise bidding for cable TV services probably reflects its performance features relative to regulation in this industry, selection problems may bias any inferences about the efficacy of franchise bidding. 


\subsubsection{Other Studies of Public Utility Governance}

Lack of cross-sectional variation in institutional forms represents a general problem for evaluating theories of regulation. By and large, there is little institutional variation within individual public utility sectors in the United States. This difficulty may be overcome, however, to the extent that governance arrangements for public utility transactions have varied over time or across countries. Two recent studies illustrate the potential of such research to provide valuable insights into the tradeoffs involved in regulation versus franchise bidding. To understand better the efficacy of franchise bidding schemes and the purposes of regulation, George Priest (1993) examined the early history of the governance of public utility transactions. According to Priest, throughout most of the 19 th century and the beginning of the 20th century, municipalities arranged for public utility services-including gas, electricity, water, sewer, street railways, and telegraph —using a method of franchise contracting similar to what Demsetz later envisioned. As Williamson and Goldberg were to predict, these contracts were typically 20 to 30 , and sometimes 50 , years in duration. Such long agreements were necessary, Priest maintained, to induce utilities to make the large investments necessary to serve a community. Furthermore, "These franchise contracts were openly sensitive to the problems of utility monopolization, and they incorporated terms limiting price and mandating features of service quality attempting to control for these problems" (1993, 301). Despite these provisions, the system of municipal regulation by franchise "suffered many problems...relating to specifying the franchise contract, adapting it over time to new conditions, and monitoring compliance with the contract for the benefit of the citizenry" $(1993,302)$.

Priest went on to relate that municipalities, after trying but failing to deal with performance problems by writing more detailed agreements, turned to more flexible, relational agreements in which performance requirements were defined only in general terms and price and the details of performance were administered by city council subcommittees or boards of arbitrators. The choice, in effect, was between regulation by contract and regulation by commission. $^{14}$ In this respect, the trend toward commission regulation of public utilities that occurred in the early 1900 s was much less dramatic an event than is sometimes characterized.

One difference between regulation by contract and regulation by commission that Priest acknowledges is that the enforceability of contracts under contract law may provide an added degree of commitment. The enhanced commitment afforded through the use of contracts is also a central element of Levy and Spiller's (1994) analysis of the use of licensing versus regulation for the governance of telecommunications transactions across countries. Like Priest, Levy and Spiller cite the fact that utilities will only be willing to make and continue investments in facilities for delivering services if they have confidence that their investments will not be appropriated through adninistrative price reductions. Licensing, they hypothesize, offers better guarantees against appropriation than regulation but offers less flexibility in response to changing conditions. The relative merits of licensing and regulation turn on

14 The similarity between contracting and regulation is also apparent in Martin Zimmerman's study of the regulatory treatment of abandoned property in the electric utility industry, in which the contractual nature of the regulatory process is highlighted. According to Zimmerman (1988), the circumstances under which the regulatory system comes under the most strain are precisely those in which recontracting and litigation problems are likely to emerge in private contracts. 
whether a country's political and legal systems provide utilities with confidence that the regulatory process will not be manipulated to their disadvantage. In a comparison of the experience of several countries, the authors find that private utilities were only willing to make sustained investments in those countries and time periods where (i) the regulatory system placed substantive restraints on regulators, (ii) the political and judicial systems placed restraints on changes in the regulaiory system itself, and (iii) institutions for enforcing the restraints both on regulators and on system changes existed. Where these institutional conditions were lacking, countries were better off relying on licensing arrangements to induce investment. In the worst case, where institutional protections are weakest, countries may have no choice but to nationalize. In countries like the United States with well-developed regulatory processes, constitutional protections, and separation of political powers, on the other hand, regulation by commission offers a balance of flexibility and commitment that is unavailable to countries with less developed institutional structures. 15

\subsection{Long-term Contracting}

Although studies of the governance of public utility transactions have provided only limited evidence of the tradeoffs between contracting and regulation that Goldberg and Williamson identified as important, there has been substantial empirical work on long-term contracts, and the choice between contracting and vertical integration, in other contexts. Cumulatively, these studies provide substantial support for the transaction-cost view of the limitations of contracting in the types of environments often encountered in public utility transactions. We begin by examining the rationale for using long-term contractual relationships in lieu of anonymous spot markets (the duration decision), and then turn to a discussion of the mechanisms by which the inflexibilities inherent in such extended agreements may be mitigated (the design issue).

\subsubsection{Contract Duration}

Among the central arguments against franchise bidding was the claim that such agreements would have to be long term to avoid the potential for hold ups given the large investments in distribution and production facilities typically needed to deliver public utility services. Paul Joskow (1987) provided evidence of the motive for long term contracts by examining the duration of long-term contracts between coal mines and electric utilities. Using data on 277 agreements in force in 1979, Joskow considered the effect on contract duration of characteristics of the environment that would affect the likelihood of ex post bargaining and, hence, the marginal benefits of being bound to a long-term contract. As relationship-specific investment became more important, the costs associated with unconstrained bargaining in the post-contractual regime would increase, resulting in a desire to implement longer term agreements.

Joskow found that the duration of coal contracts was influenced by the degree of physical asset specificity, site specificity, and dedicated assets. Coal is a heterogeneous commodity

15 Baron and Besanko (1987) analyze formally the value of commitment and note that even limited commitments that restrict regulators to deal with utilities "fairly" may be valuable. By the same token, commitment to a regulatory bureaucracy that impedes the ability of regulators to appropriate cost savings by utilities may enhance efficiency. (See. e.g., Sappington (1986).) Levy and Spiller's analysis suggests the importance of political institutions in supporting those commitments. 
and is burned most efficiently in generation facilities designed for coal with particular properties. On the East Coast, a large number of small mines produce relatively uniform quality, high BTU coal. In contrast, in the West, very large, geographically dispersed mines produce very low BTU coal with much greater quality variation. Furthermore, the East is characterized by relatively abundant transportation alternatives and shorter average distances, while the West enjoys fewer transportation alternatives and much longer average distances. As a result, to a much greater extent, electric generators in the West are tied by both their design and location to a particular mine. Site specificity is even greater where generators have been located, to save coal transportation costs, at the mine mouth. Finally, because finding alternative customers and suppliers is likely to be more difficult the larger the quantity of coal contracted for, Joskow used contract quantity to proxy for the magnitude of investments in dedicated assets.

Joskow's empirical results indicate that, in environments where relationship-specific investments are important, the agreements tend to be longer in duration. Other things the same, soal contracts in the West average 11 years longer than contracts for Eastern coal. Moreover, contracts governing the sale of coal to minemouth plants average an additional 12 years. Finally, contract length increases by 13 years for each additional million tons of coal contracted for. These findings thus strongly support the transaction cost theory of contract duration.

Whereas Joskow's analysis emphasized the benefits of long-term contracts, Crocker and Masten (1988) examined how the costs as well as the benefits of contracting affect contract duration. In general, the hazards of extending a contract to cover an additional period are likely to be larger the longer the contract and the more uncertain the transaction. In addition, contract designs that promote efficient adaptation to changing circumstances should lower the costs of being bound to long-term agreements and increase contract duration. To test these hypotheses, Crocker and Masten assembled data on long-term natural gas contracts negotiated between interstate pipelines and the owners of gas wells. During the period covered by the sample, many of the transactions were subject to well-head price regulation that limited the price pipelines were permitted to pay for gas purchases. To attract gas supplies, pipelines engaged in nonprice competition using other contract terms. Controlling for the size of appropriable quasi-rents, Crocker and Masten estimated that the resulting distortions in incentive provisions induced by price regulation reduced contract length by an average of 14 years, while the increased uncertainty in gas markets caused by the 1973 Arab oil embargo raised the cost of writing contracts and reduced the length of agreements by an additional three years.

The tradeoff between protecting specific investments and the hazards of contracting is also evident in a recent study of engineering subcontracting practices in the United Kingdom. Using survey data, Bruce Lyons (1994) found that the probability that a subcontractor had a formal contract with its "most important customer" was significantly higher the greater the share of the subcontractor's output accounted for by that customer, the greater the percent of that output specifically designed to that customer's requirements, and where production required significant investments in specific capital. The likelihood of a formal contract fell, on the other hand, where the subcontractor employed expensive, but flexible, equipment and where the firm produced an advanced technology product: the greater complexity and uncertainty likely to be associated with advanced technology products would tend to make contract specification and enforcement more difficult (compare Crocker and Reynolds (1993)). Collectively, these studies provide evidence of both the importance of contractual 
protections where exchange is supported by relationship-specific investments and the liabilities of contracting in uncertain environments or where contract terms cannot adequately accommodate the need for adjustment over time.

\subsubsection{Contract Design}

As the evidence on contract duration indicates, the design of contractual agreements is an important determinant of the hazards associated with long-term contracts. The choice of contract provisions should thus be a fundamental concern to parties contemplating the use of long-term agreements. The first and most detailed investigations of contract design from a transaction-cost perspective were studies by Paul Joskow (1985) and by Victor Goldberg and John Erickson (1987). As a precursor to his analysis of contract duration, Joskow conducted an extensive case study of the relations between electric utilities and their coal suppliers. Among other things, the study documented the variety of price and nonprice provisions transactors employed to reduce the potential for opportunistic hold-up in the presence of relationship-specific investments and to mitigate the costs of maladaptation. These data formed the foundation for his more systematic analyses of pricing provisions, which we discuss in more detail below.

Goldberg and Erickson's (1987) study examined the structure of long-term contracts between petroleum coke refiners, calciners, and their customers. Coke is a bulky product, making it expensive to store and to ship. Furthermore,

Coke is also a fire hazard and a source of pollution unless it is put in covered storage. The costs of storing coke include both the direct costs of preparing land and of providing railroad spurs, water sprays, bulldozers, and loading equipment and the opportunity cost of the land employed for storage. It also must include the possible costs arising from an accumulation of inventory, an accumulation that may cause a disruption in the refinery's operations....Economizing on inventory costs requires rapid processing to keep the total inventory low and rapid removal of inventory to lower-value storage areas $(1987,374-5)$.

At the same time that storage costs make timely removal important, transportation costs encourage petroleum coke users to locate near coke suppliers and limit the possibilities for sales to alternative customers. Given the site specificity of investments and the high costs of delay, a buyer's failure to take deliveries imposes costs on the producer:

The coker's costs depend on the rate at which coke is removed from the refinery. If coke is removed too slowly, the coker is faced with a number of costly options. It could accelerate the search for new customers, reduce the production rate, or, in the limit, shut down its coking operations. The opportunity cost of refinery products not produced is a significant element of the costs of untimely removal $(1987,375)$.

To mitigate the potential for opportunistic refusals to accept delivery by purchasers, petroleum coke contracts tended to be long-term and to contain quantity and pricing provisions crafted to assure the timely removal of petroleum coke. Full output-immediate removal contracts with substantial financial penalties for nonremoval by purchasers, as well as minimum purchase requirements, were typical. In addition, many contracts provided for price flexibility through the use of indices tying the price of coke to that of crude oil, a primary input, while others involved more open-ended negotiations which constrained opportunism by specifying minimum and maximum prices. Overall, Goldberg and Erickson concluded that the structure of the contracts reflected the desire by the parties to minimize the transaction costs of effecting exchange. 
These case studies succeeded in demonstrating the complexity of the issues involved in contracting where relationships involve nontrivial investments in durable, relationship-specific assets. Moreover, they depict in ways that more formal tests cannot the broad array of terms employed and the interactions of those terms. But although case studies are valuable for the crucial detail they offer, such studies are by their very nature vulnerable to charges of ex post rationalization, a complaint that can only be overcome through more formal statistical analysis.

Minimum Purchase Requirements. The first aspect of contract design to be formally considered was the use of minimum purchase requirements in the context of long-term natural gas supply agreements. These requirements, which have been variously referred to as "take-or-pay" or "minimum bill" provisions, required the purchaser to pay for a contractually-specified minimum quantity even if delivery was not accepted. The economic rationale for these provisions was provided by Masten and Crocker (1985), who interpret the monetary payments associated with minimum purchase requirements as liquidated damages for breach of contract by a purchaser who refuses to accept delivery. ${ }^{16}$ Such breach is efficient as long as the buyer gains more than the seller loses from the action. Requiring that the buyer pay the seller damages equal to the difference between the contract price and the seller's next best sale alternative guarantees that the buyer refuses delivery only when it is efficient to do so. The implication is that, if take-or-pay provisions are designed to provide optimal incentives for breach of contract, then the magnitude of the obligations should increase as the value of a seller's alternative sale possibilities declines.

Using data on the incidence of minimum purchase requirements in natural gas contracts between well owners and pipelines signed between 1960 and 1982, Masten and Crocker found that the magnitudes of take-or-pay requirements were negatively related to the number of pipelines serving a field, which is consistent with the optimal breach penalty argument because more buyers increase the value of a well owner's alternative sale possibilities. On the other hand, increases in the number of independent sellers located in a field, which increases the amount of drainage and reduces the value to a particular seller of storing gas in the ground for future sale, tended to result in larger take-or-pay obligations. Similar results were obtained by Mulherin $(1986 a ; 1986$ b) who examined the prevalence of take-or-pay requirements in natural gas contracts prior to the imposition of wellhead price regulation subsequent to the Phillips decision of $1954 .{ }^{17}$ Together, these results offer considerable support for the contention that efficiency considerations underlie the use and magnitude of minimum purchase requirements in long-term contractual agreements.

Contract Prices. One of the most important issues in contract design is the determination of the prices to prevail in the course of the agreement. While a fixed price is easy to stipulate at the outset, such an approach may result in substantial inefficiency if the contract price diverges from opportunity costs. For example, a contract fixing the price at a level that turns out to be below the relevant opportuniity costs at some future date gives buyers the incentive to overconsume the product in question, and encourages sellers to engage in privately profitable but socially costly opportunistic tactics to force contract renegotiation to obtain a

16 An alternative view is discussed by Hubbard and Weiner (1986), who interpret such provisions as lump-sum transfers. This issue is addressed in detail by Masten (1988).

17 Phillips Petroleum v. Wisconsin, 347 U.S. 672 [1954]. 
more favorable price.

Joskow $(1988 ; 1990)$ examined the extent to which the prices of long-term coal contracts track opportunity costs, which he defined as prices that obtain in newly negotiated agreements. In the 158 contracts where the price adjustment process could be identified, $78 \%$ contained a base price that was escalated by a formula related to production costs, such as labor, materials, and explosives indices. Joskow found that this price flexibility permitted the prices at which contractual exchange occurred in the 1970s to track market opportunity costs fairly closely. This contrasts to the situation in the early $1980 \mathrm{~s}$, where a drop in oil prices resulted in a significant reduction in the demand for coal. As a result, the market price for coal dropped substantially while the contractual price, still governed by the cost escalators, exhibited downward rigidity. Although the widening gap between contract price and opportunity costs resulted in some renegotiations, voluntary and otherwise, Joskow concluded that the majority of the agreements remained intact, perhaps because of the threat of legal sanctions. In any case, this episode poignantly illustrates the hazards associated with the adoption of inappropriate methods of price determination.

In a somewhat different vein, Hubbard and Weiner (1991) examined the level of contract prices in a sample of 1,102 natural gas supply agreements negotiated prior to 1957 to ascertain whether the prices were driven by market power or transaction cost considerations. They concluded that the negative effect of buyer concentration on contract price is indicative of some monopsony power by the pipeline purchasers but that there is also some evidence suggesting that small-numbers bargaining was an important consideration in the natural gas market.

Methods of Price Determination. While the studies discussed above were primarily concerned with the level of contractually determined prices and their ability to track contemporaneous market opportunity costs, other authors have concentrated on the processes contracting parties adopt to determine prices. Although fixed-price contracts are easy to administer and establish a well-defined division of the surplus, they generate incentives for the parties to engage in wasteful redistributive activities. One form of that behavior is the use of excessive pre-contract search (Goldberg 1985, 532):

[T] he parties could attempt to increase their share of the gains before signing the contract by improving their information on the future course of costs and prices. The more they each spend on this search, the smaller the pie. Ceteris paribus, the larger the variance of the outcomes, the more resources would be devoted to this effort. The parties, therefore, have an incentive to incorporate into the initial agreement a device that would discourage this wasteful searching. Price adjustment mechanisms can do precisely that by reducing the value of the special information.

Another source of inefficiency in long-term contracts with fixed prices is the danger that the contract price would fail to track contemporaneous market conditions, leading to a desire by one of the parties to force a renegotiation of the agreement. Goldberg refers to these efforts, which range from high-profile repudiation and breach of the contractual agreement to more subtle attempts to sabotage performance through delivery delays or degrading quality, as post-agreement jockeying, and describes a solution (Goldberg 1985, 532):

These costs would be unimportant if the parties had easy access to market alternatives; ceteris paribus, the more isolated from alternatives the contracting parties are, the more significant are the losses from poor coordination. Again, to the extent that the parties can anticipate these problems at the formation stage, the value of the exchange is reduced. If the probability of wasteful behavior increases as the divergence between 
contract price and the opportunity cost of the aggrieved party widens, price-adjustment rules which narrow the gap become increasingly attractive.

The importance of pricing provisions in mitigating pre-contract search has recently been demonstrated by Leffler and Rucker's (1991) analysis of contract provisions in the timber industry. They considered two types of contracts, the first being a lump-sum payment independent of the actual amount of timber harvested, while the second stipulates a payment per-unit of harvested timber. The fixed-payment contract gives purchasers an incentive to engage in extensive presale measurement of timber quality and quantity, which gives the buyer an informational advantage in negotiations but does nothing to enhance the value of the timber. Their hypothesis was that the variable payment per-unit contract is more likely to be adopted as presale measurement costs rise and as the cost of monitoring the harvesting activity by the seller declines. Using a sample of 188 timber contracts in North Carolina, Leffler and Rucker concluded that the mitigation of transaction costs is an important consideration in the selection of a fixed- or variable-payment compensation scheme.

Incorporating some type of price adjustment mechanism into a long-term contract thus appears to be an important element in the design decision. The problem, however, is that the relationship-specific investments that necessitated the extended agreement in the first place isolates the parties from market alternatives, so that there is no "market price" as such upon which the contract price may be conditioned. As a consequence, contracts tend to use a heterogeneous mix of arrangements to adjust prices over time. The factors influencing the choice among price adjustment processes was the concern of a recent article by Crocker and Masten (1991). The economic tradeoff is between fllexibility and precision in contractual agreements. On the one hand, very precise agreements tend to constrain opportunism but at the cost of potentially constraining the parties to take actions that may turn out to be inappropriate because of changing economic circumstances. On the other hand, loose agreements permit adaptation to changing economic realities but may open the door to opportunistic tactics.

Using data on price adjustment provisions in natural gas contracts, Crocker and Masten found that flexible open-ended renegotiation of prices is most common in contracts of longer duration where uncertainty is a particular concern, while the more precise formulaic price escalator provisions are less likely in contracts with large minimum purchase requirements. This last result suggests that flexibility in pricing and in the quantity exchanged are substitutes and that increases in the flexibility afforded the parties in one aspect of an agreenuent may necessitate a decrease in another.

The economic tradeoff between flexibility and precision is also the concern of Crocker and Reynolds (1993), who examined the optimality of incomplete contracts using data on the agreements under which the U.S. Air Force procured jet engines for F-15 and F-16 fighters. Their hypothesis is that the degree of completeness actually chosen is an optimizing decision by the parties to mitigate the transactions cost of effecting an exchange. More complete agreements mitigate ex post opportunism but at the cost of additional resources being expended on ex ante design, while looser agreements are easier to implement but leave more room for post-agreement jockeying. The price adjustment provisions in the data vary from the very precise fixed-price contract, through formulaic escalators conditioned on well-defined price indices, and include some very unstructured open-ended negotiations. Crocker and Reynolds found that characteristics of the environment that would lead to increased uncertainty and more resources being spent on ex ante design, such as extended performance horizons or a high level of technological uncertainty, led to less complete 
agreements. On the other hand, factors that would predict increased opportunism, such as a record of contractor litigiousness or the absence of alternative engine suppliers, resulted in substantially more complete contracts being signed. Again, the empirical work on price adjustment mechanisms supports the importance of transaction cost considerations in the design of contractual agreements. In particular, as the relationship becomes more enduring and the environment more uncertain, contracts tend to become more relational, the parties intentions shifting from establishing a commitment to particular terms of trade to establishing the process through which the terms of trade will ultimately be determined.

Effects of External Regulation. Regulatory interference can influence the structure of contracts. In some cases, regulation may directly delimit contractual forms, such as mandating disclosure in warranties on consumer loans. In other circumstances, long-term contracts evolve to mitigate inefficiencies caused by external regulation. This is precisely the case in Masten and Crocker's (1985) examination of take-or-pay provisions in long-term natural gas supply contracts. ${ }^{18}$ As mentioned above, that analysis indicates that such requirements play an important efficiency role in providing optimal incentives for breach of contract. These contracts were, however, subject to wellhead price regulation, which caused nonprice terms, such as take-or-pay provisions, to play a distributional role as well. Indeed, Masten and Crocker estimate that the nonprice competition caused by regulation increased the average size of take-or-pay provisions by six percentage points.

Another documented case is provided by a series of articles by Palay $(1984 ; 1985)$ examining informal contracts in contracting for rail freight services. Although most freight travels in standardized rail cars, some products require investment in specialized rail cars that are useful only for shipping a particular product and are sometimes so idiosyncratic as to be specific to a particular shipper. In order to invest in such relationship-specific investment, the railroads require some type of assurance that, after making the required investment, they would not become the targets of opportunistic behavior by their customers. While a formal long-term contract would seem to be the obvious solution, the Interstate Commerce Act (45 U.S.C. 10761-10762, 1978) placed severe restrictions on permissible contracting. Effectively, the regulations requiring nondiscrimination in rates constrained the ability of the parties to negotiate special prices for superior service standards and interfered with the railroad's ability to construct safeguards, such as minimum shipping requirements, to mitigate customer opportunism. In a study of fifty-one shipping transactions, Palay discovered extensive use of informal guarantees by the parties in an attempt to establish a long-term relationship and to give railroars the incentive to make the relationship-specific investment required for the sale of specialized transportation services. These agreements ranged from devices to adjust contract price outside of the limits imposed by the ICA to the

18 Hubbard and Weiner (1986) also argue that take-or-pay provisions were distorted by regulatory price ceilings. Their interpretation of take-or-pay provisions as lump-sum payments is factually incorrect, however. Evidence that take-or-pay provisions are adopted for their incentive effects and not as a means of distributing gains from trade is that distortions in these provisions resulted in shorter term agreements (Crocker and Masten 1988). If the principal role of take-or-pay provisions were to distribute rents, as Hubbard and Weiner maintain, then higher take provisions, by raising the value of the contract to the seller, should have led to longer term contracts.

19 Crocker and Masten (1988) estimate the average distortion in take-or-pay provisions caused by wellhead price regulation at 9 percentage points. In a related vein, Lyon (1990) examines the biases generated by state regulation on utilities' choice of long-term contracts or spot purchases to acquire their gas supplies. 
exchange of "economic hostages" (Williamson 1985) to mitigate the potential for opportunism. For example, the railroads would often agree to purchase specialized cars as long as the customer located its plant in a fashion that precluded the use of alternative shippers. Such informal agreements permitted the parties to make the investments required for exchange and to mitigate inefficiencies caused by external regulatory interference.

Overall, the empirical research on contracting lends credence to the concerns expressed by Goldberg and Williamson regarding franchise bidding and casts doubt on the general efficacy of franchise bidding as a panacea for natural monopoly. The primary attraction of the franchise bidding approach is in its apparent simplicity: Rather than requiring continual, and intrusive, regulatory oversight, inonopoly power is dissipated by a competitive auction over the supply price. Unfortunately, the presence of large and durable relationship-specific investments is likely to require the use of long-term contractual agreements. And, as the studies above indicate, the economic considerations confronted in the design of such contracts rarely result in the simple agreements often envisioned by the proponents of the franchise bidding solution. Moreover, the effectiveness of franchise contracts in accommodating change and inhibiting opportunism declines as the transactions become more uncertain and complex. This suggests the need for considering an alternative institutional solution to the problem of natural monopoly.

\subsection{Vertical Integration}

A review of the empirical literature on vertical integration is useful for two reasons. First, regulators and utilities must confront integration decisions such as whether to own or contract with supply sources. Second, internal administration of private transactions is in many respects analogous to the regulatory administration of public utility transactions. Both substitute relatively low-powered incentives and ongoing monitoring for the high-powered incentives of contractual exchange. Although the empirical literature on contracting supports Williamson's and Goldberg's claims about the practical limitations and hazards of contracting, the fact that contracting is an imperfect institution does not, by itself, establish the superiority of regulation. The efficiency of franchise bidding can only be understood in comparison to the deficiencies of administering the provision of utility services under regulation. Since the factors that aggravate contracting hazards are also likely to make regulation more difficult, the relative merits of franchise bidding and regulation will be altered only if the hazards of contracting and regulation expand at a differential rate. As noted earlier, the empirical research on franchise bidding and regulation has only begun to address the efficiency of franchise bidding in comparative terms. To the extent, however, that regulation and internal organization are analogous institutions, evidence about the efficiency and determinants of vertical integration in private transactions may provide insights into the relative efficiency of conventional and administered contracts. ${ }^{20}$

Unlike the decision to regulate, vertical integration decisions have been the subject of fairly extensive study in the transaction-cost literature. The relation that has received by far the most scrutiny is the effect of asset specificity on these decisions. Numerous studies

20 Rate-of-return regulation and internal organization are analogous institutions in that both employ low-powered incentives and relatively flexible administrative decision processes rather than courts to resolve disputes. See the discussion in section 3.1.2. 
provide case and anecdotal evidence. Paul Joskow's study of coal contracting (1985), for instance, noted that mine-mouth electric utility generators were six times more likely to own coal mines than were non-mine-mouth plants. Similarly, Stuckey (1983) reported that bauxite refiners typically owned their own mines because high transportation costs and the specificity of refineries to particular ores made mines and refineries specific to one another. Tin refining, in contrast, was less likely to be integrated backward because of lower transportation costs and the ability of refineries to handle ores from different mines (Hennert 1988).

Similar patterns of organization are found in manufacturing settings. In the early $1980 \mathrm{~s}$, despite the existence of an independent computer chip industry, computer manufacturers produced internally virtually all of their custom-designed computer chips and approximately two-thirds of such semi-custom components as gate arrays (see Masten (1984)). With the subsequent development of chip production equipment that could be reprogrammed to accommodate special chip designs, however, customized chip production shifted back to external suppliers.

An early example of the hazards of contractual exchange motivating integration in the presence of relationship-specific investments was GM's decision to integrate Fisher Body (Klein, Crawford, and Alchian 1978; Klein 1988). Originally, automobile bodies were individually constructed out of wood, a labor-intensive process that required few investments in specialized equipment. The shift to closed metal bodies occurring around 1919 required investments in giant presses and in dies for stamping body parts. GM and Fisher Body initially agreed to a ten year contract for the sale of metal auto bodies. Unanticipated increases in the demand for automobiles in the early years of the contract, however, led to frictions over price on sales exceeding those covered in the contract and the refusal of Fisher to locate production facilities closer to GM. Eventually, the tension between the two became intolerable and, by 1926, GM had acquired Fisher.

Automotive parts procurement was also the subject of the first attempt to assess the role of relationship-specific investments on integration decisions in a more systematic fashion. To determine whether relationship-specific investments led automobile manufacturers to procure parts internally, Monteverde and Teece (1982a) collected data on 133 automobile components and their procurement by GM and Ford. Arguing that the most important source of switching costs in the automotive industry was the specialized knowhow that arose in the development of new automotive components, Monteverde and Teece hypothesized that integration of production was more likely to occur for components that required a greater amount of applications engineering. As predicted, engineering-intensive components, as well as those whose design was specific to a particular manufacturer, had a significantly higher probability of being produced internally in their sample.

Monteverde and Teece's finding regarding the importance of engineering effort on integration in automotive manufacturing was later confirmed in a study by Masten, Meehan, and Snyder (1989) that used an independent sample of 118 components from the Big Three auto companies. ${ }^{21}$ In addition to testing the effects of engineering intensity, however, this study also included measures of physical asset and site specificity. Although the study again found that components requiring greater levels of engineering were significantly more likely 
to be produced internally, the authors found no significant correlation between their physical-asset and site specificity measures and the likelihood of integration. The authors' explanation of this finding is that, whereas full integration may be necessary when appropriable quasi-rents accrue to human capital, ownership of the relevant assets may be sufficient to attenuate hold ups where quasi-rents derive from investments in physical assets. Attempts by the supplier to hold up the buyer could then be countered by redeploying the assets to another supplier. ${ }^{22}$ Consistent with this, Monteverde and Teece, in a second study (1982b), found that automobile manufacturers were more likely to retain title to tooling used by suppliers to manufacture automotive components the more specialized and expensive that tooling.

The tendency for firms to take title to specialized physical assets has also been reported in other settings. In his study of rail freight contracting, Palay (1984) found that, while railroads usually owned the cars used to transport products by rail, chemical shippers owned most of their own rail cars. Unlike other rolling stock, the tank cars used to transport chemicals "usually were constructed to be substance-specific. Glass or rubber linings, specialized pressure valves, and damage control equipment are but a few examples of the unique equipment employed. Quality control and safety concerns prevented the transfer of cars across products or manufacturers" $(1984,278)$. The shipment of automotive parts also involved specialized investments. Although the boxcars used to transport automotive parts are redeployable among automotive shippers and tend to be owned by the railroads, the racks used to load and secure those parts within the boxcars are specific to the make and model of the automobile. Accordingly, ownership of the racks usually resides with the shipper (Palay $1985,168)$. Finally, in a study of defense procurement practices and regulations, Masten (1984) found that, in a sample of fifty-four investments in specialized tooling or test equipment, the government retained title all but seven instances. Those seven exceptions, moreover, either (i) involved proprietary technology or (ii) had a higher alternative use value or shorter use life than the average for the forty-seven for which title was taken.

Although vertical integration is more common in the presence of asset specificity, the choice between integration and contracting-both of which provide some level of protection against hold up-turns on the relative ability of these alternatives to accommodate complexity and uncertainty. Because the limitations of contracting become particularly acute in complex and uncertain environments, greater uncertainty and complexity generally favor integrátion over long-term contracting.

A number of studies examine the effects of asset specificity in combination with complexity and uncertainty. Masten's defense procurement study, for instance, analyzed the make-or-buy decisions of a prime contractor for an aerospace system involving 1,887 component specifications. While components specifically designed for use in this system were significantly more likely to be produced internally, the effect was greatest for more complex components. Specifically, the lack of alternative uses for a component raised the

22 Although relocating assets wculd not be an option for site-specific investments, in principle at least, the same effect could be achieved by evicting a supplier from a buyer-owned factory. Another possible explanation for the absence of an effect of these variables is the poor quality of the asset specificity measures. Masten, Meehan, and Snyder (1991) found that the correlation between asset specificity rankings by two independent respondents was particularly low in their sample of shipbuilding components. 
probability of internal procurement from less than $1 \%$ to $31 \%$ for relatively simple items but from $2 \%$ to $92 \%$ for more complex components.

Asset specificity and uncertainty have also been shown to prompt forward integration into distribution as well as backward integration into production. The earliest of these studies is Anderson and Schmittlein's (1984) examination of distribution practices in the electronic components industry. Using a sample of 145 companies, Anderson and Schmittlein found that manufacturers were significantly more likely to integrate marketing of their products (that is, use direct, employee salespeople rather than independent sales representatives), the greater a salesperson's investments in company-specific human capital and the more difficult it is to measure a salesperson's performance. A second study by Anderson (1985) confirmed her earlier findings and revealed, in addition, that the interaction of uncertainty and asset specificity had a large and significant effect on the probability of using an integrated sales force. George John and Barton Weitz (1988) reported similar findings for the percent of sales made through direct rather than independent channels (wholesalers, distributors, or retailers) using a sample of 87 industrial goods manufacturers.

In addition to the conventional measures of asset specificity, there is growing evidence that "temporal specificity," or the extent to which timing is critical to efficient performance, is an important determinant of organizational form. Even where assets are not otherwise specialized to particular transactors, the need for timely performance and the difficulty of finding substitute performance on short notice may create hold up possibilities. Masten, Meehan, and Snyder's (1991) study of procurement decisions in the naval construction industry provides the most systematic evidence of the importance of timing so far. As in other construction settings, but in contrast to manufacturing, shipbuilding requires that a large number of tasks be performed in strict sequence on a large, immobile object. Because interruptions at an early stage in the construction process can disrupt all subsequent operations, delay becomes a potentially effective strategy for eliciting price concessions. Consistent with this concern, Masten, Meehan, and Snyder found, among other things, that both the costs of contractual procurement and the probability of integration rose as the importance of scheduling increased.

Timing considerations were also found to be the critical determinant of organizational form in Craig Pirrong's (1994) study of ocean shipping. Ocean shipping is remarkable in that spot, medium- and long-term contracts, and vertical integration are all common in this industry even though neither the physical nor human assets involved are relationship specific by the standard definitions; ships are by their very nature redeployable geographically and, though their design may be specialized to a particular cargo type, it is never specific to a particular customer. Pirrong attributes the existence of long-term contracts and vertical integration in shipping to temporal specificities that arise because of the difficulty of arranging alternative shipping services for some commodities on short notice. He argues that contracting practices in the market for the commodity being shipped, the thickness of the shipping market, and whether the commodity is most efficiently shipped aboard specialized or general purpose tonnage all affect the severity of the hold up problem in bulk shipping and finds that the duration of shipping contracts and the incidence of vertical integration broadly align with these considerations in fourteen bulk shipping markets.

Differences in the need for timely removal also explain the structure of contracts in Goldberg and Erickson's previously discussed study of petroleum coke transactions (1987): the use of full-output, immediate-removal contracts where the costs of inventory accumulation at the coker were high, and adoption of fixed-quantity contracts between cokers and 
small calciners whose costs of inadequate supply were large. Temporal specificity may also arise because a product's value is inherently time dependent, like fashions (see Masten and Snyder (1993)) and newspapers (see Klein, Crawford, and Alchian (1978)); because the product is perishable, as is the case with agricultural commodities (see Knoeber (1983) and Gallick (1984)); or because, like natural gas and electricity, the product is costly to store (see White (1995)).

Finally, while the literature emphasizes variations in the hazards of market exchange, variations in the costs of managing transactions internally may also affect the differential efficiency of integration. Masten et al. (1991), for instance, provide evidence supporting Coase's early speculation that the costs of internal organization tend to increase with "the dissimilarity of the transactions" (Coase 1937; 1991, 25). Noting that construction mainly involves the coordination of relatively low-technology, labor-intensive activities, the authors reasoned that internal organization costs and, hence, the probability of integration, would be lower the more labor intensive and the less engineering intensive the production process. Their findings support Coase's contention and raise questions about the interpretation of results regarding the effects of engineering intensity on integration decisions in the automotive industry (see the discussions of Monteverde and Teece (1982a) and Masten et al. (1989) above). ${ }^{23}$

In sum, a considerable body of evidence supports the claim that asset specificity increases the hazards of market exchange and that contracts become a less satisfactory means of protecting relationship-specific investments the more complex or uncertain the transaction. In those circumstances, private parties routinely forego the benefits of market governance in favor of the "administrative" alternative. The same forces that make internal organization the preferred alternative in private transactions, as we will argue below, also favor the adoption of regulation as the relevant administrative alternative to contracting in public utility settings.

\subsection{Governance Choice and Performance}

An important question left unanswered by these studies is just how important is organizational form to performance. While the empirical research supports the assertion that private decision makers are sensitive to transaction-cost concerns, the success of a theory in explaining observed patterns of organization reveals little about the cost of failing to choose the correct organizational form. For many regulatory problems, knowing which governance alternative offers superior efficiency may not be enough; we may also need to quantify the difference. As Paul Joskow has remarked in this context, "how much would we actually lose if we required utilities to enter into long-term contracts with independent suppliers...in order to improve the effectiveness of regulatory scrutiny" if vertical integration were actually the more efficient organizational arrangement (1991b, 81-82)?

23 Other evidence that attribute and geographic similarity favor integration was found by Davidson and McFetridge $(1984 ; 1985)$ who looked at the choice of international technology transfer modes. John and Weitz (1988) also included a measure of territorial sparseness, measured as the percent of a sales person's tirne spent on travel, in their study of forward integration into distribution channels. Although they interpret this variable differently, the result that firms are less likely to integrate sales channels covering sparse territories is consistent with the greater difficulty of monitoring sales people that are on the road covering broad territories. 
Economists have made few attempts to quantify the effects of governance on performance. ${ }^{24}$ Nevertheless, the research that has been conducted suggests that governance choices can have potentially large effects on efficiency. A study by Brickley, Dark, and Weisbach (1991) of the effects of statutory restrictions on termination rights in franchise contracts, for instance, found that the loss of this contractual instrument resulted in a drop on average of $6 \%$ of the value of the franchisors' stock. Since companies both own and franchise outlets, and termination laws do not affect the efficiency of company-owned outlets, this estimate understates the cost to franchisors of regulatory interference in their operations. ${ }^{25}$

The study of shipbuilding procurement by Masten, Meehan, and Snyder (1991) discussed earlier also attempted to quantify the importance of organizational choices to performance. Using censored regression techniques and a measure of the costs of planning, directing, and supervising production of vertically integrated components and activities, the authors estimated that mistaken integration of the typical subcontracted component in their sample (that is, integrating a component that should have been subcontracted) would increase transaction costs by approximately $70 \%$, or from $17 \%$ to $29 \%$ of the total value of the components. Mistaken subcontracting (contracting work that should have been integrated), on the other hand, would raise the custs of governing a representative integrated transaction by a factor of almost three, or from $13 \%$ to $38 \%$ of the component's value. The magnitude of those costs, moreover, generally vary with respect to the attributes of transactions in ways predicted by transaction-cost theory. ${ }^{26}$

Existing studies of the performance implications of organizational choices, though limited in number and scope, suggest that organizational form has a potentially significant impact on efficiency. Considerable room for additional research exists, however, on the performance implications both of regulatory policy decisions and of organizational choices more generally. ${ }^{27}$ Nevertheless, the studies cited above suggest methods by which the relation between organization and performance can be quantified and assessed.

\section{Lessons for the Current Regulatory Debate}

The traditional rationale for public utility regulation has been the existence of noncompetitive markets occasioned by economies of scale in production. Baumol and Sidak's recent analysis of telecommunications regulations, for instance, "proceeds on the premise-almost

24 Although there are literally hundreds of studies that attempt to measure the relation between organizational form and financial performance (mostly in the strategic management and finance literatures), these studies suffer from serious methodological problems (see Masten 1993).

25 The absence of data on the value of franchisees prohibited Brickley et al. from estimating the effects of franchise termination restrictions on franchisees and thus prevented quantification of the joint benefits of termination clauses.

26 Pablo Spiller (1985), in a somewhat less direct test of transaction-cost propositions, found that the gains to merging firms were significantly larger and the reductions in systematic risk significantly greater the closer they were located to one another, suggesting that the returns to integration are larger where location ties firms together.

27 Along these lines, DeCanio and Frech (1993) examined the effects of changes in Federal Energy Regulatory Commission regulations on natural gas prices. Although they found that regulatory changes favoring spot over contract purchases raised contract prices, they did not attempt to quantify the performance implications of these changes. 
universally accepted in principle, although widely violated in practice-that the proper role of regulation is that of a substitute for competitive market forces where those forces are weak or absent" $(1994,5)$. "The regulator's task," they continue,"then becomes a two-part undertaking: first, to determine the rules of behavior that the regulated firm could have been expected to follow if it had operated free of regulation in a market with fully effective competitive forces; second, to constrain the regulated firm to behave as it would in such a competitive market, and to circumscribe its behavior no less and no more than this" (1994, 5; emphasis in original). Operationally, this view of the regulator's task reduces to getting the price right, that is, of discovering and instituting prices that support competitive outcomes.

The transaction cost-administered contracting perspective, in contrast, views the problem of regulation in process terms. As Goldberg $(1976,431)$ has argued, the key to understanding regulation is to note

...the fundamental similarity between regulation and a private contract for the right to serve....[I]n searching for a rationale for regulation we should look not at the shape of the long-run average cost curve, but instead at the complexities involved in devising and administering such a contract....[N]atural monopoly industries will be characterized...not by their alleged decreasing average costs, but by the features which make long-term relationships between consumers and producers desirable...

Foremost among the features making long-term contracts desirable is the opportunistic potential inherent in a small-numbers exchange setting occasioned by relationship-specific investments (Goldberg 1976; Williamson 1976). Given the need to make such investments, the governance of public utility transactions becomes less a problem of discovering the right price than of identifying the governance structure that economizes on the cost of arriving at and adjusting the terms of trade over the course of the relationship.

A transaction-cost orientation stands to contribute to the debate over several recent trends in regulatory policy. One of these is the growing support among both academics and policy practitioners for price-cap regulation as an alternative to rate-of-return regulation. (See, e.g., Baumol and Sidak (1994), Liston (1993), and the articles published in the Symposium on Price-Cap Regulation, RAND Journal of Economics, Autumn 1989. ${ }^{28}$ Although specifics differ, the crucial feature of price-cap regulation proposals is that prices are set and adjusted based on factors other than the utility's realized costs. Under price-cap regulation, such as the RPI-X scheme employed in the United Kingdom, prices adjust in relation to an exogenous price index less an expected or target rate of productivity growth. Among the advantages ascribed to price-cap regulation is that, because prices are not automatically adjusted down if the utility reduces its costs, utilities have an incentive both to improve productive efficiency and to innovate. In effect, price-cap regulation represents an effort to establish the highpowered incentives of contractual relationships in a regulatory setting.

Recent research on price adjustment processes, however, warns of the hazards of employing overly formulaic price adjustment processes in precisely the types of settings that characterize public utility transactions (Goldberg and Erickson 1987; Crocker and Masten 1991; Crocker and Reynolds 1993). In private contracts, those hazards include costly efforts 
to contrive cancellation, evade performance, or force a renegotiation of the terms of trade-plus corresponding efforts to counteract such behavior-the prospects of which rise when realized prices leave one of the parties disadvantaged relative to the other. To mitigate those costs, private long-term contracts often employ a variety of escape clauses or adopt price adjustment processes better suited to accommodating changing circumstances. (See Joskow (1985); Crocker and Masten (1991); and Crocker and Reynolds (1993). ${ }^{29}$ For example, contracting parties tend to employ more relational price adjustment processes that take advantage of realized cost and demand information the longer the term of the contract (Crocker and Masten 1991) and the greater the potential for or history of opportunism (Crocker and Reynolds 1993). Contractors also tend to adjust prices more frequently the more uncertain the environment in which they operate (Crocker and Masten 1991; Crocker and Lyon 1994). Overall, the research on price adjustment in private contracts suggests that price-cap regulation could work adequately for short periods or under relatively stable conditions but that too rigid a regulatory structure poses the risk of political and legal conflicts if shifts in technological or demand conditions leave either consumers or utilities greatly disadvantaged. ${ }^{30}$ Issues in the design and evaluation of price-cap regulation for which transaction-cost research can offer insights include: what adjustment processes should be employed, how often prices should be adjusted, when formulaic prices should be abandoned or the formula itself be modified, and how such modifications should be effected (compare Acton and Vogelsang (1989)) ? $^{31}$

While such insights derive from the similarity between regulation and contracts, a better understanding of the differences between court and regulatory administration is also important to the design of regulatory structures. Efforts to instill regulation with contract-like, high-powered incentives begs the question: why regulation rather than franchise contracting? If the desire is to replicate market incentives, why not the real thing? Priest's (1993) analysis of the historical shift from regulation by contract to regulation by commission suggests that the costs of accommodating uncertainty using court administration over the long horizons involved in public utility projects were high relative to the costs of accommodating change by regulatory commission. As Levy and Spiller (1994) point out, the principal advantage of regulation is its greater flexibility. Yet that flexibility also tends to undermine the commitment needed to instill high-powered incentives in regulatory relationships. In this regard, regulatory bureaucracies and bureaucratic process may serve a useful purpose in limiting regulator discretion (see Sappington (1986)). Optimal regulatory design will also depend on the political and legal environment in which it operates (Levy and Spiller 1994).

Another prominent regulatory issue concerns the appropriate boundaries of regulated firms. Disintegration and unbundling of utility services have been either required or strongly

29 Private contracts also use a variety of nonprice clauses such as take-or-pay provisions and other types of quantity restrictions to discourage evasion. See, for instance, Masten and Crocker (1985) and Goldberg and Erickson (1987).

30 One question is whether price realizations under RPI-X that left utilities unable to cover costs would survive constitutional protections barring the taking of private property without just compensation. For a theoretical analysis of price-cap versus cost-based regulation that raises similar concerns about the inflexibility of price-cap regulation, see Schmalensee (1989).

31 Kovacic (1991) documents the interesting parallels between the inherent limitations of price caps used by public utilities and the problems encountered in the implementation of fixed-price contracts by the Department of Defense in weapons acquisition contracts. 
encouraged in the telecommunications, electricity, and natural gas sectors, with the ostensible goal of fostering competition in those stages of production and distribution capable of supporting numerous participants and concentrating regulation exclusively on natural monopoly or bottleneck services. Only passing and superficial attention has been given, however, to potential losses in organizational efficiency that may result from such disintegration. In their recent analysis of telecommunications regulation, for example, Baumol and Sidak note ambivalently the trend toward integration of video, data, and conventional and wireless yoice transmission and allude to the potential loss of scope economies from regulatory constraints preventing the regional Bell operating companies from competing in businesses such as wireless communications, cable television, and long-distance service (1994, 15, 19). A transaction-cost orientation stands to inform the discussion both conceptually and practically. At the conceptual level, transaction-cost economics has counseled that scope economies in production imply only shared use of the factors of production, not common ownership of those factors (see Teece (1982)). At the practical level, transactioncost economics is better suited than orthodox economics to evaluate the source and magnitude of economies associated with the integration of various services and stages of production.

Recent changes in the regulation of the transportation and sale of natural gas provide another illustration. Traditionally, interstate pipelines served as gas merchants, who purchased gas from independent well owners and then transported and sold the commodity under long-term contracts to local distribution companies (LDCs). Beginning with the special marketing programs of the early 1980's, however, the Federal Energy Regulatory Administration (FERC) embarked on an ambitious program to unbundle gas sales and transportation. This effort, which culminated in FERC Orders 436, 500, and 636, was designed to transform pipelines into common carriers providing only transportation services to the end users on a nondiscriminatory basis. The result has been a complete transformation of the natural gas market into one where end users negotiate directly with well owners for gas supplies and then arrange for transport by a regulated interstate pipeline. Indeed, this regime change became quite popular amongst LDCs, who substituted away from their long-term contractual obligations toward less expensive spot supplies in the wellhead markets. The development of well-functioning spot markets, moreover, has altered the economics of that contracting that remains. (See Lyon and Hackett (1993) and Alger and Toman (1990).) In contrast to prederegulation agreements, such contracts generally index price to spot prices and often provide for termination on relatively short notice by either party.

While the goal of open-access has clearly been to introduce market mechanisms in the previously regulated gas industry, the long-term effects of these policies are still unclear. Through its policies, FERC has effectively substituted rate-of-return regulation of transmission services for private governance through long-term, bundled contracts. Although a substantial spot market for gas supplies in the field has evolved, the regulatory changes supporting those developments occurred contemporaneously with the collapse in oil prices and corresponding weakness in the gas market, obviating the need for major new investment in pipeline capacity. Circumstances in the United States may now favor greater reliance on unbundled, spot transactions, especially in locations such as Oklahoma and Southern Louisiana where the density of producers and pipelines greatly attenuates the specificity of production and transmission capacity. In such locations, however, neither long-term contracts nor regulation of transmission are likely to be necessary to support investments in transmission capacity. Whether rate-of-return regulation of transmission services will prove 
as effective as long-term, bundled contracts in supporting investments in new transmission capacity in more sparsely-served areas were gas demand to rise again is an open question. To the extent LDC's and other commercial purchasers of natural gas, in contrast to consumers in end-user markets, have an advantage over regulators in assessing the costs and benefits of those investments and associated governance alternatives, bundled contracts might well prove more efficient. As Teece $(1990,21)$ notes,

It is not by accident that nowhere in the world - Canada, United States, Australia, Europe-has the natural gas industry evolved by itself into a fragmented structure. Integration efficiencies often dictate bundling. This view may be contrary to the new conventional wisdom, but it is consistent with historical evidence and recent developments in organizational economics.

Ultimately, the merits of the current regulatory structure turn on comparative institutional considerations of the type summarized in this study.

The disintegration debate has also extended to the electrical power industry, which has traditionally been structured as large regional monopolies engaged in the generation, transmission and distribution of electricity. The extensive horizontal span of individual suppliers and the numerous power-sharing agreements often observed between independent utilities have been justified on the basis of increased reliability resulting from coordinated supply decisions. Moreover, the substantial degree of vertical integration, which extends from generation through distribution, is generally viewed as an artifact of the economies associated with internal dispatchability of generation in response to load fluctuations. This is consistent with the observations of Masten, Meehan, and Snyder (1991) and Pirrong (1993), who find that the costs of contracting rise steeply as the timing of performance becomes more important, thereby favoring internal procurement. These coordination efficiencies, in conjunction with the natural monopoly aspects of the local distribution network, resulted in an industry characterized by both extensive vertical integration and a lack of competition in the distribution of electricity.

This industry is, however, entering a period of substantial transformation, prodded by both legislative opportunities and political realities. The opportunity is provided by the Public Utility Regulatory Policy Act of 1978 (PURPA), which set the stage for utilities to purchase at least a portion of their power requirements from unregulated nonutility generators. While the intent of PURPA was only to encourage the use of cogeneration and other alternative small power production technologies, the effect has been to alter fundamentally the perceived supply options facing utilities and regulators. At the same time, the reality of increasingly stringent prudence reviews, coupled with the political and environmental impediments associated with the construction of large, central station generation facilities, has encouraged utilities to concentrate on their distribution and transmission functions and to look elsewhere for their power requirements. ${ }^{32}$

While the displacement of regulated power generation by arms-length unregulated supply agreements has been applauded in some quarters as a prima facie triumph of competitive markets, important challenges have yet to be resolved. As Joskow $(1989,142)$ notes in this

32 Although independent power producers currently account for less than 5\% of generating capacity in the United States, " ...it appears that up to half of the new generating capacity that is expected to come on line over the next decade will come from independent power producers..." (Joskow 1991a, 68). 
regard,

Probably the most fundamental issues associated with the current trend toward disintegration and the development of competitive wholesale generation markets are associated with questions about alternative organizational arrangements...that might sacrifice some of the theoretical efficiencies of vertical and horizontal integration in order to reduce some of the inefficiencies of regulation by relying more on competition to allocate generation resources...

The question becomes more acute when one recognizes that the institutional alternative to the vertical integration of generation and distribution is unlikely to be an anonymous spot market but, rather, a more structured and extended exchange relationship.

To the extent the siting of generation facilities and the construction of transmission lines continue to involve relationship-specific investments, the exchange environment in the wholesale power market will entail the prospect of opportunistic behavior. In such circumstances, transactions cost analysis predicts that the preferred institutional alternative to vertical integration is likely to be the use of long-term contracts. Indeed, this is precisely what has been observed by Cameron (1992), who examined contracts between independent generators and utilities in Connecticut, Massachusetts, New Jersey, and Virginia, and found that the duration of such contracts averaged 23 years. Similarly, Joskow $(1989,173)$ notes that:

... long term supply contracts with [qualifying facilities] are generally negotiated at least five years before the first delivery of power and specify delivery and payment schedule for periods of ten to twenty years thereafter.

Decreases in the minimum efficient scale of power generators and the use of power pools and coordinated exchanges that improve access to the distribution network by independent generators are likely to reduce the importance of relationship-specific investments in the market for electricity (see White (1995)). Nevertheless, transmission and generation are likely to continue to exhibit substantial temporal specificities, implying the need for institutional alternatives to spot exchange. ${ }^{33}$

\section{Conclusions}

The purpose of this article has not been to offer a full analysis of the implications of transaction-cost economics to regulatory issues but, rather, to provide an overview of and guide to the empirical literature in transaction-cost economics for regulatory economists. By viewing rate-of-return regulation as a long-term agreement between customers and the regulated firm, we are able to apply the insights gleaned from the now substantial literature on contracting to understand better the regulatory relationship. For example, one would expect an arms-length franchise bidding approach to be most effective when relationshipspecific investments are less important, so that incumbents would have less of an opportunistic advantage at franchise renewal. Alternatively, an exchange scenario requiring the protection of extensive relationship-specific investment would imply the need for an ex- 
tended, and potentially complex, contractual relationship. Indeed, given the uncertainties associated with performance over distant time horizons, the preferred choice may be to forego a contractual relationship entirely, and opt for adjudication provided by regulatory governance. The ability of the parties to write complete franchising agreements would make a contracting relationship more attractive, while environmental circumstances leading to an incomplete specification of duties would favor a more formal regulatory structure.

The fundamental lesson provided by transaction cost economics is that organization form matters and that, depending on the specifics of the environment, some modes of governance will be preferred to others. This observation is particularly germane in the current regulatory setting, where less intrusive and more impersonal mechanisms are often advocated as remedies for the perceived inefficiencies and arbitrariness of traditional rate-of-return regulation. When considering these alternatives, the economic tradeoffs inherent in the transaction cost approach provide guidance on appropriate modifications, as well as warn of potential pitfalls.

An increasingly common regulatory reform is the use of the market processes for activities which have historically been within the purview of regulation. Examples of this approach include the interstate sale of natural gas, where anonymous spot markets have replaced formal price regulation, and wholesale power markets in which electric utilities are increasingly purchasing electricity from independent sources in lieu of internal generation. To the extent that relationship-specific investments are likely to continue to be important in both of these industries, however, the appropriate alternative to regulation is the use of long-term relational contracts rather than spot markets. Misguided deregulation efforts forcing spot market exchange over long-term contracts or formal regulation may, therefore, induce substantial inefficiencies.

A less extreme, but similarly directed, approach is the effort to resolve the uncertainties associated with traditional regulation by substituting for that process a more mechanical, and, hence, predictable form of governance. The mechanism design approach to regulation maintains the traditional natural monopoly perspective on the role of regulation and seeks to solve the regulatory problem by designing a complete "regulatory contract" with clearly enunciated and structured incentives. But, as the empirical literature on organizational choice and design demonstrates, in contexts where exchange requires relationship-specific investments and the environment is complex or uncertain, the optimal governance mode is an incomplete relational contract or, in the extreme, the use of vertical integration or regulatory oversight. Efforts to create highly structured, formal, incentives in a regulatory setting may be misplaced if the regulatory structure is itself a response to the hazards of governing exchange through an arms-length franchise contract. Put differently, if credible incentive regulation were feasible, franchise bidding would likely have dominated at the outset, and regulation would not have been necessary. Ultimately, the only recourse to the problems commonly associated with regulation may be the application of increased diligence on the part of regulators and those that oversee them.

\section{References}

Acton, J. P. and I. Vogelsang. 1989. "Introduction to Symposium on Price-Cap Regulation." Rand Journal of Economics 20 (Autumn): 369-372.

Alger, D. and M. Toman. 1990. "Market-Based Regulation of Natural Gas Pipelines." Journal of Regulatory Economics 2 (September): 263-280. 
Anderson, E. 1985. "The Salesperson as Outside Agent or Employee: A Transaction Cost Analysis." Marketing Science 4: 34-254.

Anderson, E. and D. C. Schmittlein. 1984. "Integration of the Sales Force: An Empirical Examination." Rand Journal of Economics 15: 385-395.

Baron, D. P. and D. Besanko. 1987. "Commitment and Fairness in a Dynamic Regulatory Relationship." Review of Economic Studies 54: 413-436.

Baumol, W. J. and J. G. Sidak. 1994. Toward Competition in Local Telephony. Cambridge, MA: The MIT Press.

Beil, R. O., Jr., P. T. Dazzio, Jr., R. B. Ekelund, Jr., and J. D. Jackson. 1993. "Competition and the Price of Municipal Cable Television Services: An Empirical Study." Journal of Regulatory Economics 5 (December): 401-416.

Brickley, J. A., F. H. Dark, and M. S. Weisbach. 1991. "The Economic Effect of Franchise Termination Laws." Journal of Law and Economics 34 (April): 101-132.

Cameron, L. 1992. "The Impact of Procurement Regime on the Price Paid for Independent Generation.” CEPR Publication No. 222, Stanford University (June).

Carroll, K. A. and D. J. Lamdin. 1993. "Measuring Market Response to Regulation of the Cable TV Industry.” Journal of Regulatory Economics 5 (December): 385-400.

Chadwick, Sir Edwin. 1859. "Results of Different Principles of Legislation and Administration in Europe; Of Competition for the Field, as Compared with Competition within the Field, of Service." Journal of the Royal Statistical Society (September): 381-420.

Coase, R. H. 1937. "The Nature of the Firm.” Economica (November): 386-405. (Reprinted in O. E. Williamson and S. G. Winter, eds. 1991. The Nature of the Firm: Origins, Evolution, and Development. New York: Oxford University Press.)

Coase, R. H. 1960. "The Problem of Social Cost." The Journal of Law and Economics 3 (October): $1-44$.

Cohen, L. 1982. "A Spot Market for Electricity: Preliminary Analysis of the Florida Energy Broker." Rand Corporation (February): N-1817-DOE.

Crew, M. A. and R. Harstad. 1992. "Franchise Bidding with Vickrey Auctions: How to Regulate Utilities." Economic Innovations in Public Utility Regulation (M. Crew, ed.). Kluwer Academic Publishers: Boston.

Crocker, K. J. and T. P. Lyon. 1994. "What do 'Facilitating Practices' Facilitate?: An Empirical Investigation of Most-Favored-Nation Clauses in Natural Gas Contracts." Journal of Law and Economics 37 (October): 297-322.

Crocker, K. J. and S. E. Masten. 1988. “Mitigating Contractual Hazards: Unilateral Options and Contract Length." Rand Journal of Economics (Autumn): 327-343.

Crocker, K. J. and S. E. Masten. 1991. "Pretia ex Machina? Prices and Process in Long-Term Contracts." Journal of Law and Economics 34 (April): 69-99.

Crocker, K. J. and K. J. Reynolds. 1993. "The Efficiency of Incomplete Contracts: An Empirical Ana'ysis of Air Force Engine Procurement." Rand Journal of Economics 24 (Spring): 126-146.

Davidson, W. H. and D. McFetridge. 1984. "International Technology Transactions and the Theory of the Firm." Journal of Industrial Economics 32 (1984): 253-264.

Davidson, W. H. and D. McFetridge. 1985. "Key Characteristics in the Choice of International Technology Transfer Mode." Journal of International Business Studies: 5-21.

DeCanio, S. J. and H. E. Frech. 1993. "Vertical Contracts: A Natural Experiment in Gas Pipeline Regulation." Journal of Institutional and Theoretical Economics: 370-392.

Demsetz, H. 1968. "Why Regulate Utilities?" Journal of Law and Economics 11 (April): 55-66.

Gallick, E. C. 1984. Exclusive Dealing and Vertical Integration: The Efficiency of Contract in the Tuna Industr;: Bureau of Economics Staff Report to the Federal Trade Commission. (Excerpted in S. E. Masten, Case Studies in Contracting and Organization. New York: Oxford University Press, forthcoming).

Goldberg, V. P. 1976. "Regulation and Administered Contracts." Bell Journal of Economics 7 (Autumn): 426-448. 
Goldberg, V.P. 1981. "Pigou on Complex Contracts and Welfare Economics." Research in Law and Economics 3: 39-51.

Goldberg, V. P. 1985. "Price Adjustment in Long-Term Contracts." Wisconsin Law Review: 527-543.

Goldberg, V. P. and J. R. Erickson. 1987. "Quantity and Price Adjustment in Long-Term Contracts: A Case Study in Petroleum Coke." Journal of Law and Economics 31 (October): 369-98.

Grossman, S. J. and O. D. Hart. 1986. "The Costs and Benefits of Ownership: A Theory of Vertical and Lateral Integration." Journal of Political Economy 94: 691-719.

Hennert, J. F. 1988. "Upstream Vertical Integration in the Aluminum and Tin Industries." Journal of Economic Behavior and Organization 9: 281-299.

Hubbard, R. G. and R. J. Weiner. 1986. "Regulation and Long-Term Contracting in U.S. Natural Gas Markets." Journal of Industrial Economics: 31-79.

Hubbard, R. G. and R. J. Weiner. 1991. "Efficient Contracting and Market Power: Evidence from the U.S. Natural Gas Industry." Journal of Law and Economics 34 (April): 25-68.

Isaac, R. M. 1991. "Price Cap Regulation: A Case Study of Some Pitfalls of Implementation." Journal of Regulatory Economics 3 (June): 193-210.

John, G. and B. Weitz. 1988. "Forward Integration into Distribution: An Empirical Test of Transaction Cost Analysis." Journal of Law, Economics, and Organization 4 (Fall): 337-355.

Joskow, P. L. 1985. "Vertical Integration and Long-Term Contracts: The Case of Coal-Burning Electric Generation Plants.” Journal of Law, Economics and Organization 1 (Spring): 33-79.

Joskow, P. L. 1987. "Contract Duration and Relationship-Specific Investments: Evidence from Coal Markets." American Economic Review (March): 168-185.

Joskow, P. L. 1988. "Price Adjustment in Long-Term Centracts: The Case of Coal." Journal of Law and Economics, 31 (April): 47-83.

Joskow, P. L. 1989. "Regulatory Failure, Regulatory Reform, and Structural Change in the Electrical Power Industry." Brookings Papers on Economic Activity: Microeconomics: 125-199.

Joskow, P. L. 1990. "The Performance of Long-Term Contracts: Further Evidence from Coal Markets." Rand Journal of Economics 21 (Summer): 251-274.

Joskow, P. L. 1991. "The Evolution of an Independent Power Sector and Competitive Procurement of New Generating Capacity." Research in Law and Economics: 63-100. (1991a).

Joskow, P. L. 1991. "The Role of Transaction Cost Economics in Antitrust and Public Utility Regulatory Policies." Journal of Law, Economics, and Organization 7 (Spring): 53-83. (1991b).

Klein, B. 1988. "Vertical Integration as Organizational Ownership: The Fisher Body-General Motor Relationship Revisited." Journal of Law, Economics, and Organization 4 (Spring): 199-213.

Klein, B., R. G. Crawford, and A. A. Alchian. 1978. "Vertical Integration, Appropriable Rents, and the Competitive Contracting Process." Journal of Law and Economics 21 (October): 297-326.

Knoeber, C. R. 1982. "An Alternative Mechanism to Assure Contractual Reliability." Journal of Legal Studies 12 (June): 333-343.

Kovacic, W. E. 1991. "Commitment in Regulation: Defense Contracting and Extensions to Price Caps." Journal of Regulatory Economics 3 (September): 219-240.

Laffont, J. J. and J. Tirole. 1987. “Auctioning Incentive Contracts." Journal of Political Economy 95 (October): 921-937.

Leffler, K. B. and R. R. Rucker. 1991. "Transactions Costs and the Efficient Organization of Production: A Study of Timber-Harvesting Contracts." Journal of Political Economy 99 (October): 1060-1087.

Levy, B. and P. T. Spiller. 1994. "The Institutional Foundations of Regulatory Commitment: A Comparative Analysis of Telecommunications Regulation." Journal of Law, Economics, and Organization 10: 201-246.

Liston, C. 1993. "Price-Cap versus Rate-of-Return Regulation.” Journal of Regulatory Economics 5: 25-48.

Lyon, T. P. 1990. "Spot and Forward Markets for Natural Gas: The Effects of State Regulation." Journal of Regulatory Economics 2 (September): 299-316.

Lyon, T. P. and S. C. Hackett. 1993. "Bottlenecks and Governance Structures: Open Access and 
Long-Term Contracting in Natural Gas." Journal of Law, Economics, and Organization 9 (October): $380-398$.

Lyon, T. P. and M. A. Toman. 1991. "Designing Price Caps for Gas Distribution Systems." Journal of Regulatory Economics 3 (June): 175-192.

Lyons, B. R. 1994. "Contract Specific Investment: An Empirical Test of Transaction Cost Theory." Journal of Economics \& Management Strategy 3 (Summer): 257-278.

Masten, S. E. 1984. "The Organization of Production: Evidence from the Aerospace Industry." Journal of Law and Economics 27 (October): 403-417.

Masten, S. E. 1988. "Minimum Bill Contracts: Theory and Policy." Journal of Industrial Economics: 85-97.

Masten, S. E. 1993. "Transaction Cost, Mistakes, and Performance: Assessing the Importance of Governance.” Managerial and Decision Economics 14 (March-April): 119-129.

Masten, S. E. and K. J. Crocker. 1985. "Efficient Adaptation in Long-Term Contracts: Take-or-Pay Provisions for Natural Gas." American Economic Review 75 (December): 1083-1093.

Masten S. E., J. W. Meehan, and E. A. Snyder. 1989. "Vertical Integration in the U.S. Auto Industry: A Note on the Influence of Transaction Specific Assets." Journal of Economic Behavior and Organization 12: 265-273.

Masten, S. E., J. W. Meehan, and E. A. Snyder. 1991. "The Costs of Organization." Journal of Law, Economics and Organization 7: 1-25.

Masten, S. E. and E. A. Snyder. 1993. "United States versus Shoe Machinery Corporation: On the Merits." Journal of Law and Economics 36 (April): 33-70.

McAfee, R. P. and J. McMillan. 1987. "Competition for Agency Contracts." Rand Journal of Economics 18 (Summer): 296-307.

Monteverde, K. and D. J. Teece. 1982. "Supplier Switching Costs and Vertical Integration in the Automobile Industry." Bell sournal of Economics 13 (Spring): 206-213. (1982a).

Monteverde, K. and D. J. Teece. 1982. "Appropriable Rents and Quasi-vertical Integration." Journal of Law and Economics 25: 321-328. (1982b).

Mulherin, J. H. 1986. "Complexity in Long-Term Contracts: An Analysis of Natural Gas Pricing." Journal of Law, Economics and Organization 2 (Spring): 105-108. (1986a).

Mulherin, J. H. 1986. "Specialized Assets, Governmental Regulation, and Organizational Structure in the Natural Gas Industry." Journal of Institutional and Theoretical Economics 142: 528-541. (1986b).

Palay, T. M. 1984. "Comparative Institutional Economics: The Governance of Rail Freight Contracting." Journal of Legal Studies 13: 265.

Palay, T. M. 1985. "Avoiding Regulatory Constraints: Contracting Safeguards and the Role of Informal Agreements." Journal of Law, Economics, and Organization 1: 155-176.

Pechman, C. 1993. Regulating Power: The Economics of Electricity in the Information Age. Norwell, MA: Kluwer Academic Publishers.

Pigou, A. C. 1932. The Economics of Welfare, 4th edition. London: Macmillan. (Reprinted 1962).

Pirrong, S. C. 1993. "Contracting Practices in Bulk Shipping Markets: A Transaction Cost Explanation." Journal of Law and Economics 36 (October) 937-976.

Posner, R. A. 1969. "Natural Monopoly and its Regulation." Stanford Law Review 21 (February): 548-643.

Posner, R. A.. 1972. "The Appropriate Scope of Regulation in the Cable Television Industry.” Bell Journal of Economics and Management Science 3 (Spring): 98-129.

Prager, R. A. 1989. "Franchise Bidding for Natural Monopoly: The Case of Cable Television in Massachusetts." Journal of Regulatory Economics 1 (June): 115-132.

Prager, R. A. 1990. "Firm Behavior in Franchise Monopoly Markets." Rand Journal of Economics 21 (Summer): 211-225.

Prager, R. A. 1992. "The Effects of Deregulating Cable Television: Evidence from the Financial Markets." Journal of Regulatory Economics 4 (December): 347-364.

Priest, G. L. 1993. "The Origins of Utility Regulation and the 'Theories of Regulation' Debate." 
Journal of Law and Economics 36 (April): 289-323.

Riordan, M. H. and D. E. M. Sappington. 1987. "Awarding Monopoly Franchises." American Economic Review 77 (June): 375-387.

Sappington, D. 1986. "Commitment to Reguiatory Bureaucracy." Information Economics and Policy 2: $243-258$.

Schmalensee, R. 1989. "Good Regulatory Regimes." Rand Journal of Economics 20 (Autumn): 417-436.

Sherman, R. 1989. The Regulation of Monopoly. Cambridge, UK: Cambridge University Press.

Spiller, P. T. 1985. "On Vertical Mergers.” Journal of Law, Economics, and Organization 1 (Fall): 285-312.

Stuckey, J. 1983. Vertical Integration and Joint Ventures in the Aluminum Industry. Cambridge, Mass: Harvard University Press.

Teece, D. J. 1990. "Structure and Organization of the Natural Gas Industry." Energy Journal: 1-36.

Teece, D. J. 1982. "Towards an Economic Theory of the Multiproduct Firm." Journal of Economic Behavior and Organization 3 (March): 39-63.

Walker, G. and D. Weber. 1984. "A Transaction Cost Approach to Make-or-Buy Decisions." Administrative Science Quarterly 29:373.

Walker, G. and D. Weber. 1987. "Supplier Competition, Uncertainty and Make-or-Buy Decisions." Academy of Management Journal 30: 589.

White, M. W. 1995. "Valuing Market Trading Mechanisms: Evidence from Electricity Markets." Mimeo, University of California Department of Economics, (January).

Williamson, O. E. 1971. "The Vertical Integration of Production: Market Failure Considerations." American Economic Review 61 (May): 112-123.

Williamson, O. E. 1975. Markets and Hierarchies: Analysis and Antitrust Implications. New York: The Free Press.

Williamson, O. E. 1976. "Franchise Bidding for Natural Monopolies-in General and with Respect to CATV." Bell Journal of Economics 7 (Spring): 73-104.

Williamson, O. E. 1979. "Transaction-Cost Economics: The Governance of Contractual Relations." Journal of Law and Economics. 22 (Oclober): 233-262.

Williamson, O. E. 1985. The Economic Institutions of Capitalism. New York: The Free Press.

Williamson, O. E. 1991. "Comparative Economic Organization: The Analysis of Discrete Alternatives." Administrative Science Quarterly: 269-296.

Zimmerman, M. 1988. "Regulatory Treatment of Abandoned Property: Incentive Effects and Policy Issues." Journal of Law and Economics 31 (April): 127-144.

Zupan, M. A. 1989. "Cable Franchise Renewals: Do Incumbent Firms Behave Opportunistically?" Rand Journal of Economics 20: 473-482. (1989b).

Zupan, M. A. 1989. "The Efficacy of Franchise Bidding Schemes in the Case of Cable Television: Some Systematic Evidence." Journal of Law and Economics 32 (October): 401-456. (1989a)

Zupan, M. A. 1989. "A Test for Regulatory Lag and the Role Played by Periodic Contract Renewals in Mitigating Such Lag in Local Cablc Franchise Relationships." Journal of Regulatory Economics 1 (March): 1-20. (1989c). 